\author{
UNIVERSIDADE DE SÃO PAULO \\ ESCOLA DE COMUNICAÇÃO E ARTES \\ Programa de Pós-Graduação em Ciência da Informação
}

ISADORA DOS SANTOS GARRIDO STEIMER

\title{
CURADORIA E CRÍTICA
}




\section{ISADORA DOS SANTOS GARRIDO STEIMER}

\section{CURADORIA E CRÍTICA}

Dissertação apresentada ao Departamento de Informação e Cultura - CBD, da Escola de Comunicações e Artes da Universidade de São Paulo, como requisito parcial para a obtenção do título de Mestre em Ciência da Informação.

Área de Concentração: Cultura e Informação.

Orientadora: Profa. Dra. Giulia Crippa. 
Autorizo a reprodução e divulgação total ou parcial deste trabalho, por qualquer meio convencional ou eletrônico, para fins de estudo e pesquisa, desde que citada a fonte.

Catalogação na Publicação

Serviço de Biblioteca e Documentação

Escola de Comunicações e Artes da Universidade de São Paulo

Dados inseridos pelo(a) autor(a)

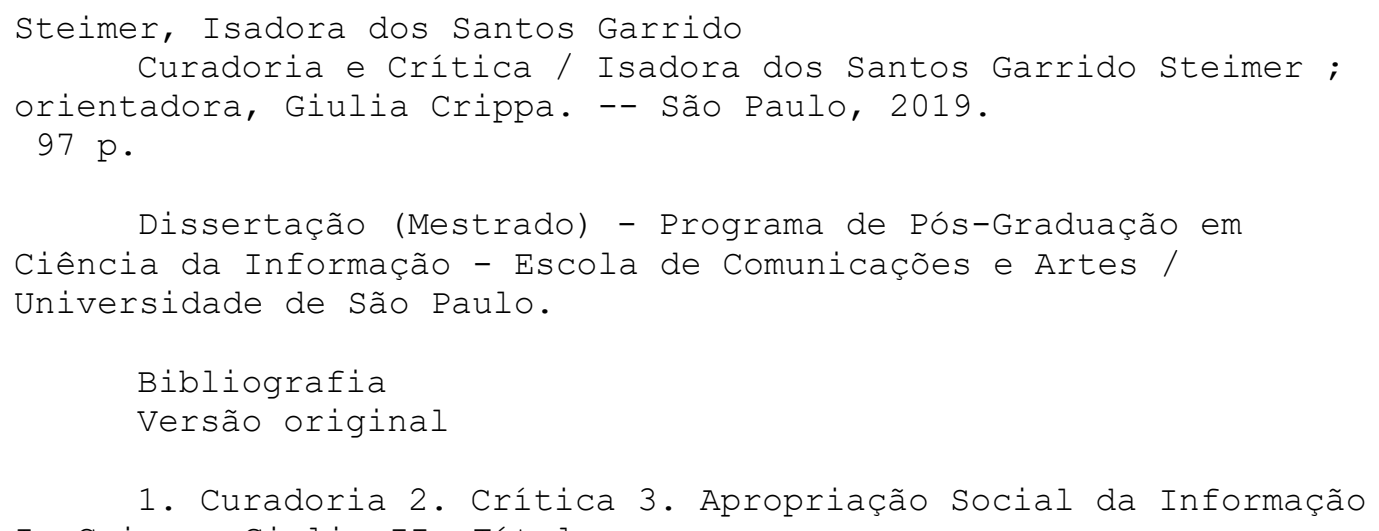

1. Curadoria 2. Crítica 3. Apropriação Social da Informação I. Crippa, Giulia II. Título.

CDD $21 . e d \cdot-020$ 


\section{FOLHA DE APROVAÇÃO}

Nome: STEIMER, Isadora dos Santos Garrido

Título: Curadoria e Crítica

Aprovado em:

Banca Examinadora:

Prof.(a). Dr.(a):

Instituição:

Julgamento:

Prof.(a). Dr.(a):

Instituição:

Julgamento:

Prof.(a). Dr.(a):

Instituição:

Julgamento: 
Ao meu pai. 


\section{AGRADECIMENTOS}

Aos meus pais, por tudo.

À minha irmã Victoria, por torcer sempre por mim.

A prof. Dra. Giulia Crippa, que acreditou desde o início na viabilidade deste projeto.

Por todo o apoio e por ser uma inspiração constante.

A prof. Dra. Lucia Maciel Barbosa de Oliveira, por supervisionar meu estágio docência. Aprendi muito com suas aulas e ensinamentos.

Ao Grupo Saraiva e aos meus gestores diretos. Cada um, ao seu modo, por terem compreendido a importância deste e desta etapa para mim.

Às room-mates de quatro patas: Kali, Maya e Sati, pelas distrações e pelo ócio.

Ao Márcio Botelho, por acreditar em mim, desde o primeiro dia.

Ao Ser Supremo do Universo. 


\section{RESUMO}

STEIMER, Isadora dos Santos Garrido. Curadoria e Crítica. 2019. 97 f. Dissertação (Mestrado em Ciência da Informação) - Escola de Comunicação e Artes, Universidade de São Paulo, 2019.

Este estudo visa pesquisar o tema de Curadoria a partir do contexto de publicações científicas em periódicos de Ciência da Informação (Cl) no Brasil. Para tanto, foi realizado o mapeamento de periódicos científicos dos estratos $A 1$ a B2, seguido de busca e seleção de artigos que contemplavam o termo via título, resumo, palavraschave e/ou texto. A questão da dissonância do significado do termo foi elaborada e desenvolvida por meio da compreensão do contexto e do conceito de informação, considerando o referencial teórico onde foram pontuadas questões culturais relativas a organização. Em 15 periódicos selecionados, foram recuperados 33 artigos sobre 0 tema e 109 termos únicos e relacionados ao tema de Curadoria. Por meio de Análise de Conteúdo, foi possível verificar que boa parte da produção acadêmica associa a Curadoria ao mundo Digital e principalmente à Preservação Digital, em um contexto acadêmico e científico. Pela granularidade dos temas, a Curadoria ainda se relaciona com conteúdo produzido na web mas ainda de forma muito emergente. Por fim, é entendido que a pluralidade de compreensões sobre o tema não deveria compartimentalizar seu estudo, mas sim relacionar a interdependência de seus significados, considerando o hibridismo de acordo com as experiências do usuário.

Palavras-chave: Apropriação Social da Informação; Ciência da Informação; Crítica; Curadoria. 


\begin{abstract}
STEIMER, Isadora dos Santos Garrido. Curation and Criticism. 2019. 97 f. Dissertation (Master in Information Science) - School of Communication and Arts, University of São Paulo, 2019.

This study aims to research the theme of Curation from the context of scientific publications in Information Science $(\mathrm{Cl})$ journals in Brazil. To this end, we carried out the mapping of scientific journals of strata A1 to B2, followed by search and selection of articles that contemplated the term via title, abstract, keywords and/or text. The question on the dissonance of the meaning of the term was elaborated and developed through the comprehension of the context and the concept of information, considering the theoretical framework where cultural questions regarding information organization were punctuated. In 15 selected journals, 33 articles on the topic and 109 unique terms related to Curation were retrieved. Through Content Analysis, it was possible to verify that much of the academic production associates Curation with the Digital world and especially with Digital Preservation, in an academic and scientific context. Due to the granularity of the themes, Curation still relates to content produced on the web but still very emerging. Finally, it is understood that the plurality of understandings on the subject should not compartmentalize its study, but relate the interdependence of its meanings, considering the hybridity according to the user's experiences.
\end{abstract}

Key-words: Curation. Criticism. Information Science. Social Appropriation of Information. 


\section{SUMÁRIO}

1 INTRODUÇÃO

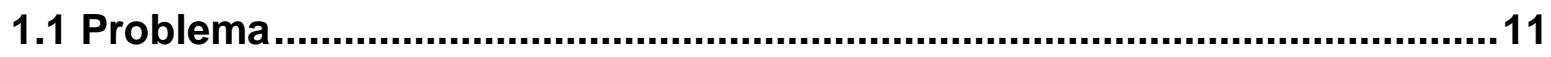

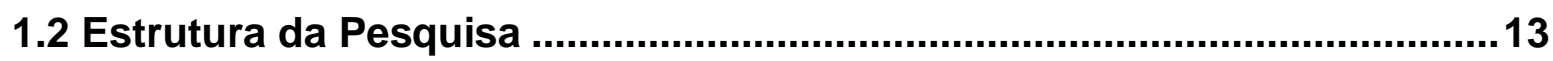

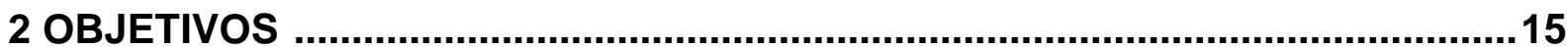

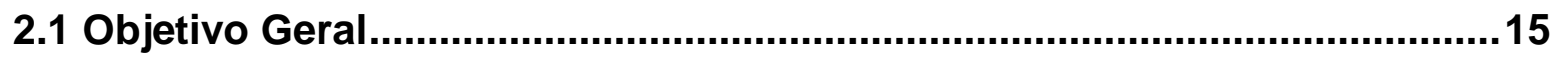

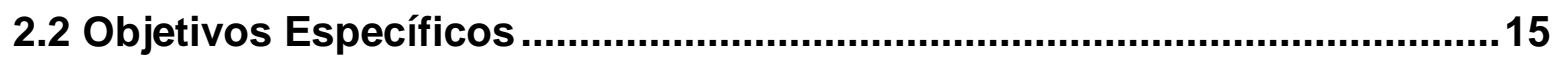

3 CONTEXTOS E CONCEITOS DE INFORMAÇÃO .............................................16

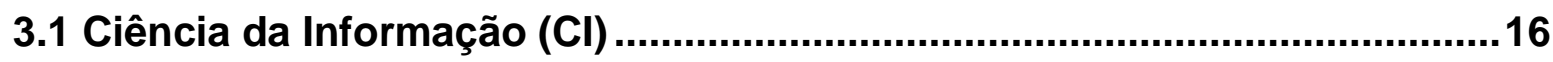

3.2 Organização da Informação (OI) ...............................................................18

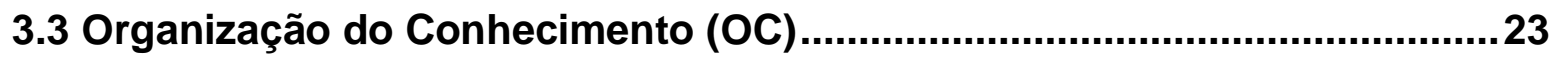

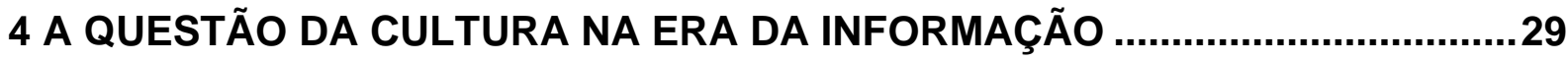

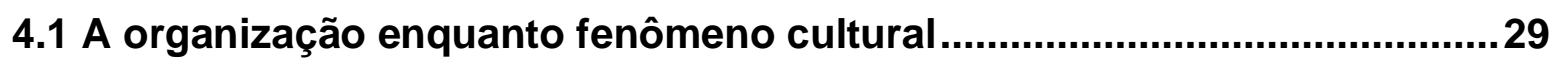

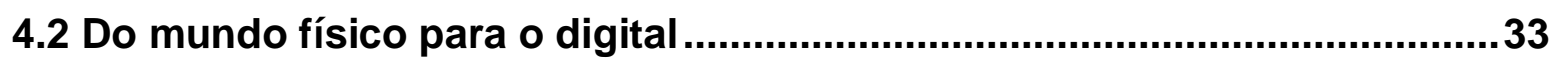

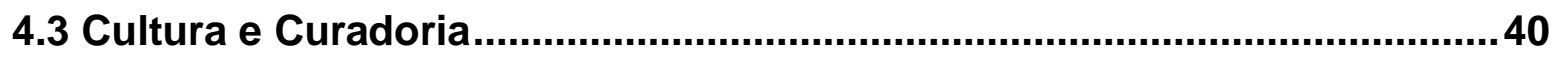

5 CURADORIA: ASPECTOS E PREMISSAS TEÓRICO-CONCEITUAIS ...............48

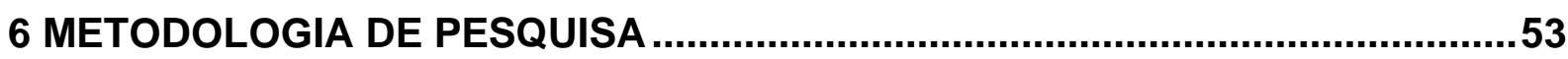

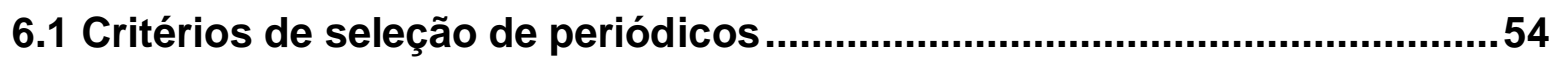

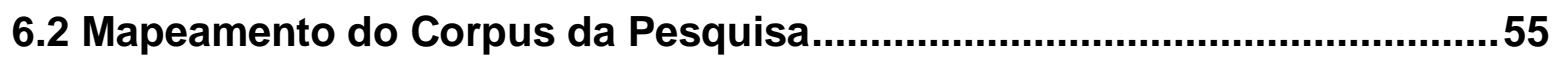

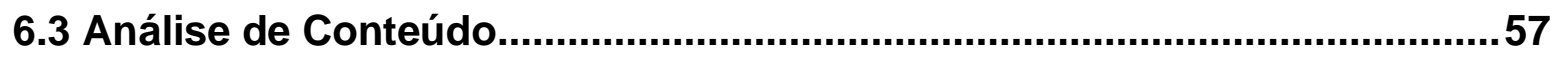

7 RESULTADOS E DISCUSSÃO

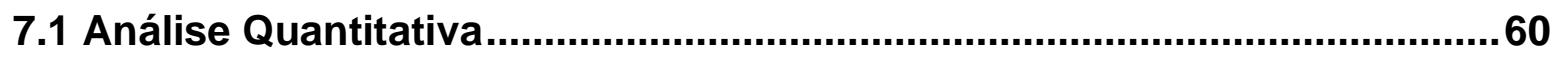

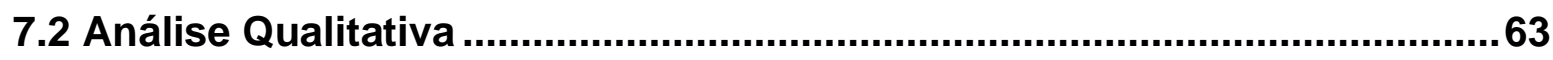

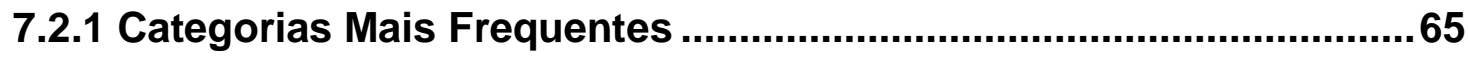

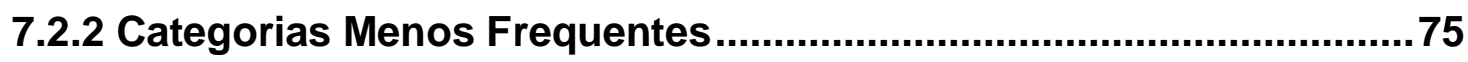

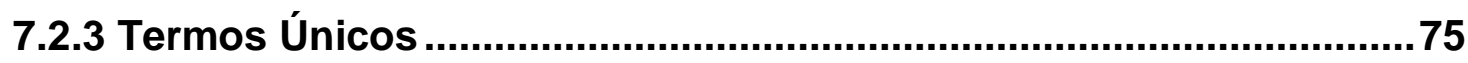


APÊNDICES ....................................................................................86

APÊNDICE A - Artigos sobre Curadoria Recuperados ...................................87

APÊNDICE B - Frequência de termos atribuídos aos artigos recuperados ......92 


\section{INTRODUÇÃO}

A Curadoria, seus processos e produtos, têm tido grande destaque na área de Ciência da Informação $(\mathrm{Cl})$ na última década. Embora sua prática e viabilização tenha sido realizada em diferentes áreas do conhecimento incluindo a biologia, as artes e a comunicação, a Curadoria também abrange as áreas de arquivologia, museologia e Biblioteconomia, se estendendo assim à $\mathrm{Cl}$ como um todo. Identifica-se, a partir do uso do termo, um assunto de caráter interdisciplinar, que pode ser compreendido sob diferentes perspectivas, com a possibilidade de ser ressignificado pragmaticamente em contexto dinâmicos, mas que necessita ser investigado de modo mais aprofundado e sistematizado.

O presente trabalho se insere na linha de pesquisa de "Apropriação Social da Informação", uma vez que seu objeto de pesquisa não trata diretamente do fazer, dos processos e produtos de Curadoria em si, mas da análise pela via dos processos de Comunicação Científica, principalmente em relação aos diversos contextos de uso do termo.

Uma vez que existe certa dissonância de significado e no uso do termo Curadoria, se faz necessário uma análise mais compreensiva. A pesquisa, então, encontra o seu alinhamento na linha de pesquisa de "Apropriação Social da Informação" uma vez que compreende estudos que estão centrados nos seguintes itens que se adequam à sua descrição:

- Dispositivos: a pesquisa foi realizada em periódicos científicos digitais nacionais, sendo este o seu principal dispositivo de análise;

- Práticas culturais: a própria Comunicação Científica e a publicação de artigos em si como prática recorrente da cultura científica;

- Dinâmicas: utilização e significados atribuídos ao termo Curadoria em contextos variados.

Uma vez que serão mobilizados conceitos como como mediação, apropriação simbólica do termo, tecnologias de informação e cultura, acredita-se que o projeto possua a aderência necessária à linha de pesquisa em questão, se adequando à 
proposta e à descrição de Apropriação Social da Informação ${ }^{1}$. Como o conceito do termo Curadoria possui variabilidade - além de estar intimamente atrelado a uma questão de comunicação científica - a pesquisa leva a um estudo de cunho mais terminológico que instrumental.

Assim sendo, uma análise sistematizada dos artigos publicados na área sobre o tema pode trazer um maior esclarecimento, tanto sobre seu uso, bem como sobre possíveis novas de tendências de pesquisa.

\subsection{Problema}

A motivação para a criação do projeto de pesquisa surgiu a partir de questionamentos que já vinham sendo desenvolvidos desde a graduação em Biblioteconomia e Documentação, concluída em 2011.

Logo, a presente pesquisa se trata de uma evolução de pesquisas ${ }^{2}$ realizadas anteriormente que incluem: um trabalho de conclusão de curso (com o tema "Organização da Informação: análise nas teses e dissertações em Ciência da Informação no Brasil") e duas pesquisas de Iniciação Científica, a saber, "Organização da Informação: Análise Conceitual" (2010-2011) e "Periódicos Científicos on-line: organização institucional de portais em arquivos abertos" (2008-2009), sendo esta última publicada como artigo ${ }^{3}$ em periódico científico da área, em 2010.

Ao longo do desenvolvimento do mestrado, a preocupação foi a de convergir os interesses de pesquisa atuais com o histórico da trajetória pessoal. Para tal, ao longo da conclusão dos créditos obrigatórios, foi desenvolvido o artigo "O papel da Cultura na Organização do Conhecimento" para a disciplina de Cultura e Informação, aprofundando um pouco mais as referências em relação tema de Organização do Conhecimento e seus desdobramentos. A questão da Cultura e seu papel durante a graduação frequentemente era compreendida como algo à parte dos processos de

\footnotetext{
1 Disponível em: http://www3.eca.usp.br/pos/ppgci/apresentacao/mestrado-doutorado-academico 2 Currículo Lattes de Isadora dos Santos Garrido Steimer: http://lattes.cnpq.br/8086552937465866 3 GARRIDO, I. S; RODRIGUES, R. S. Portais de Periódicos Científicos Online: Organização institucional das publicações. Perspectivas em Ciência da Informação, [S.I.], v. 15, n. 2, p. 56-72, jun. 2010. Disponível em: http://portaldeperiodicos.eci.ufmg.br/index.php/pci/article/view/943/732
} 
Biblioteconomia - e o próprio enfoque pessoal na área também sempre foi mais tecnicista e, principalmente, voltado para a gestão e a Organização da Informação (OI) como um todo.

A partir de um novo percurso de pesquisa e de novos conhecimentos adquiridos ao longo do curso das disciplinas de mestrado, preocupou-se justamente em explorar a questão da Cultura na Era da Informação, desta vez não como pano de fundo, mas como o próprio contexto no qual a Comunicação Científica está inserida. Neste sentido, a ideia de pesquisar periódicos científicos como um de seus representantes legítimos, não apenas se consolidou como tomou outra dimensão. Portanto, a busca pelo termo "Curadoria" não se refere apenas ao seu conceito em si, mas também ao próprio ato comunicativo de quem publica na e para a $\mathrm{Cl}$. Partem-se das premissas já expostas sem, no entanto, deixar de questionar: quais são as possíveis apropriações do termo "Curadoria" pela comunidade científica de $\mathrm{Cl}$ ?

Isto posto, chega-se ao problema da Curadoria. Neste estudo em específico, a $\mathrm{Cl}$ foi selecionada como área do conhecimento a ser mapeada, através de suas publicações científicas periódicas que estejam indexadas na Plataforma Sucupira (antiga Plataforma WebQualis Capes).

De acordo com Bazi e Silveira (2007, p. 132), o sistema conceitual (das ideias) juntamente com o social (de atores) pode constituir uma disciplina científica. Os autores entendem que, para se consolidar, a ciência necessita transmitir seus conhecimentos operacionalizando seus atos comunicativos. Tais atos comunicativos são viabilizados principalmente pela linguagem, seja ela natural ou especializada, repercutindo diretamente na organização de suas estruturas - sociais e científicas. A terminologia de um domínio científico, seu uso corrente e suas mudanças que ocorrem ao longo do tempo, determinam o nível de maturidade e a própria consolidação do domínio de conhecimento em questão.

Uma vez que as abordagens são distintas levando em conta diferentes disciplinas e a variedade de autores que publicam sobre o assunto em livros e artigos de periódicos científicos, faz-se necessário um estudo que sintetize o que tem sido produzido referente ao tema.

A importância deste tipo de trabalho se centraliza tanto na questão de 
verificação processos curatoriais já conhecidos, como o desenvolvimento de coleções e catálogo, atuações em museus e exposições de arte, bem como da emergência de plataformas digitais e colaborativas de compartilhamento da informação.

É importante frisar que o termo selecionado foi "Curadoria" apenas, independentemente de ser digital ou física. A inquietação reside não somente na definição "o que é" Curadoria, mas em procurar buscar onde está a Curadoria na $\mathrm{Cl}$, por uma via de pensamento mais pragmática.

A contribuição deste estudo para a área de $\mathrm{Cl}$ pode ser considerada inédita, uma vez que ainda inexistem publicações que tenham abordado o tema em periódicos nacionais, levando em consideração o termo "Curadoria" isoladamente.

\subsection{Estrutura da Pesquisa}

Neste primeiro capítulo, foi realizada a introdução e a apresentação do tema de pesquisa e sua justificativa de adequação à linha de pesquisa de Apropriação Social da Informação. O problema da pesquisa também foi abordado, sendo vinculado ao histórico de pesquisa anteriores e os objetivos de pesquisa foram delineados. No capítulo 2, os objetivos gerais e específicos da pesquisa serão apresentados.

No Capítulo 3 - "Conceitos e Contextos de Informação" - foi realizada uma breve contextualização dos conceitos adquiridos previamente que se relacionam com o tema a ser pesquisado, a saber: a grande área de Ciência da Informação e as disciplinas de Organização da Informação e Organização do Conhecimento, suas diferenças e intersecções.

Explorando mais profundamente a OC, a questão da cultura na era da informação foi abordada no Capítulo 4, onde foram revisados artigos sobre o tema, de acordo com a perspectiva de Olson, Mazzochi e García-Gutierrez, autores de diferentes backgrounds e com visões distintas sobre o tema. A questão da organização enquanto fenômeno cultural, a transição do mundo físico para o digital e o papel da curadoria foram abordados, levando em consideração movimentações mais contemporâneas acerca do objeto informação. 
No capítulo 5, foram abordados alguns aspectos e premissas teóricoconceituais acerca do tema de Curadoria. A intenção não foi a de realizar uma definição à priori, mas sim compreender o termo de modo mais abrangente.

$\mathrm{Na}$ metodologia de pesquisa, ao longo do capítulo 6, foram delineados os critérios utilizados para o desenvolvimento o trabalho e o mapeamento do corpus de pesquisa. Uma breve análise de conteúdo foi realizada, de acordo com a metodologia de Bardin (2010).

O capítulo 7 explora o material bibliográfico recuperado a partir de análise quantitativa e qualitativa. Os resultados e discussões são abordados de acordo com as categorias mais e menos frequentes e as categorias únicas. Finalmente, no Capítulo 8 são dispostas as considerações finais sobre a pesquisa. 


\section{OBJETIVOS}

\subsection{Objetivo Geral}

Contribuir com reflexões acerca do conceito de Curadoria dentro do campo da Ciência da Informação, partindo de uma análise nas publicações periódicas na área.

\subsection{Objetivos Específicos}

- Realizar o levantamento e identificação da produção de artigos em periódicos científicos que abordem o tema de Curadoria;

- Revisar a literatura recuperada e criar um mapeamento, a partir do método de análise de conteúdo acerca do tema de Curadoria;

- Analisar possíveis contextos culturais de Organização da Informação e de Conhecimento que se apropriem da Curadoria como prática; 


\section{CONTEXTOS E CONCEITOS DE INFORMAÇÃO}

Acredita-se que toda a pesquisa possua suas premissas e seus pontos de partidas. A intenção deste capítulo é a de delimitar o tema conceitualmente, listando alguns pressupostos e conceitos que se relacionam em menor ou maior medida com o objeto de pesquisa central, a Curadoria. Parte-se, então, dos seguintes contextos: a grande área de Ciência da Informação - sua relação com a Biblioteconomia e seus possíveis estudos e práticas; a Organização da Informação e seus princípios e a Organização do Conhecimento e seus fundamentos.

\subsection{Ciência da Informação (Cl)}

Saracevic (1995) entende que definições não criam uma área, no entanto compreende que é importante prover sempre uma ideia do escopo dos problemas que possam ser endereçados. De modo superficial, é possível afirmar que a Ciência da Informação é um campo interdisciplinar principalmente preocupado com a análise, coleta, classificação, manipulação, armazenamento, recuperação e disseminação da informação.

Frequentemente caracterizada como área de natureza interdisciplinar, a Ciência da Informação se relaciona com discussões que envolvem campos da Biblioteconomia, Ciência da Computação, Ciência Cognitiva e Comunicação, sendo que a maioria dos problemas se relacionam com as questões de acesso e recuperação da informação, consideradas por Saracevic uma das principais fontes das relações interdisciplinares.

A criação da primeira pós-graduação da área no Brasil ocorreu em 1970, pelo Instituto Brasileiro de Bibliografia e Documentação, atual Instituto Brasileiro de Informação em Ciência e Tecnologia (IBICT). De acordo com Souza e Stumpf (2009), segundo a Tabela de Áreas do Conhecimento, do Conselho Nacional de Desenvolvimento Científico e Tecnológico (CNPq) e da Coordenação de Aperfeiçoamento de Pessoal de Nível Superior (CAPES), a Cl antes de se tornar uma área específica da Grande Área das Ciências Sociais Aplicadas I, era subordinada à 
área de Comunicação.

Em relação a área de Comunicação, Mostafá (1996) compreende que a Cl se constituiu como disciplina no espaço do meio entre a Biblioteconomia e as comunicações, uma vez que se propôs a trabalhar a comunicação científica no próprio interior da produção científica, ao invés de se preocupar com seus agentes e atores:

\begin{abstract}
A área de comunicações [...] sempre visou a comunicação científica nos meios de massa; a área de comunicações trabalha com as notícias de ciência nos jornais e na tevê, por exemplo. Mas nunca foi sua preocupação entender a produção científica enquanto uma rede de citações. Isso fez a Ciência da Informação (MOSTAFÁ, 1996, p. 2).
\end{abstract}

Buckland (2012), por sua vez, compreende que é preciso aceitar o contexto cultural da $\mathrm{Cl}$ e que este contexto poderia nos levar a contribuições mais realistas e mais efetivas para nossa sociedade permeada por documentos. Para o autor, não se trata meramente de um questionamento cultural, mas de reconhecer a noção central de informação como relacionadas à aprendizagem e ao conhecimento. Desta maneira, a área pode ser considerada como essencialmente cultural:

[...] a Ciência da Informação preocupa-se com engajamento cultural. Abordagens formais e quantitativas são extremamente valorosas, mas 0 campo em si mesmo é incorrigivelmente cultural. Métodos formais e quantitativos, embora úteis, nunca podem ser mais do que papéis auxiliares altamente valorizados. Caracterizar a recuperação da informação e bibliometria como ciências do artificial é uma descrição, não uma crítica. [...] No final, podemos ver que nossos argumentos têm de algum modo uma forma circular (BUCKLAND, 2012, p. 8).

Tálamo e Smit (2007) conceitualizam uma desconstrução do que seria a Cl através da sugestão de uma linha do tempo sobre o Pensamento Informacional. As autoras falam sobre o desenvolvimento da informação enquanto objeto através de uma perspectiva histórica e de análise de propostas de 4 diferentes vértices do pensamento que ajudaram a construir a área: Gabriel Naudé (acesso e informação pública), Melvil Dewey (coleção e serviços), Paul Otlet (documentação e conteúdo) e Derek John De Solla Price (informação e poder).

A proposta é de compreender a $\mathrm{Cl}$ como uma ciência pós-moderna, dirigida 
pela necessidade de resoluções de problemas apresentados pelas ciências e tecnologias clássicas, no entanto, cada uma em seu tempo. Para Tálamo e Smit (2007, p. 48) é preciso "encarar a Ciência da Informação como um processo autônomo no ambiente da pós-modernidade, desvinculado da elaboração de um pensamento histórico-informacional".

Ainda, compreendem que um dos objetivos da $\mathrm{Cl}$ é o de formulação de sistemas significantes que funcionem como memória social dos conteúdos registrados para fins de recuperação da informação e que constituem a informação qualificada para recuperação e uso dos conteúdos originais.

Este pensamento corrobora em certa medida com a abordagem pragmática de entendimento da área de Gracioso e Saldanha (2011):

\begin{abstract}
Antes, [a $\mathrm{Cl}]$ pode refletir com suas comunidades de deliberação contextuais sobre os processos sociais que sedimentam representações. Sob um olhar pragmatista, o homem deve ser crítico à ideia de que a informação é bela, deve ser provocado sobre como a informação é construída, deve ser lembrado de que a informação é apenas a esfera de narrativas múltiplas demarcadamente um fetiche do século XX - e nunca será a única pedra de toque que soluciona as crises da racionalidade (GRACIOSO; SALDANHA, 2011, p. 125-126).
\end{abstract}

Em Ciência da Informação e Filosofia da Linguagem, os autores convidam ao pensamento do 'pragmatismo informacional', nos convidando a explorar quais contribuições científicas podem conduzir o estudo da informação para as relações sociais, antes de dizer se há ciência para a informação. $O$ foco, para este intento, seria o da tradição pragmática de atentar para uma $\mathrm{Cl}$ que "estuda, antes, narrativas, e não necessariamente delimita fenômenos, ou busca naturezas - mesmo sua metanatureza", destacam Gracioso e Saldanha (2011).

\title{
3.2 Organização da Informação (OI)
}

O primeiro contato com o tema de Organização da Informação se obteve em 2010, ao longo da realização da pesquisa "Organização da Informação: uma análise conceitual", no qual se dedicou a análise do termo - e temas relacionados - a partir 
de levantamento bibliográfico na base de dados internacional Library and Information Science Abstracts (LISA).

Para o trabalho supracitado, foi utilizado como referência o conceito de Organização da Informação conforme compreendido por Bräscher e Café (2010). As autoras também analisaram o conceito de Organização do Conhecimento que será abordado no próximo capítulo.

Em um primeiro momento, as autoras compreendem OI principalmente como:

[...] um processo que envolve a descrição física e de conteúdo dos objetos informacionais. O produto desse processo descritivo é a representação da informação [...] Alguns tipos de representação da informação são construídos por meio de linguagens elaboradas, especificamente para os objetivos da OI (BRÄSCHER, CAFÉ, 2010, p. 92).

A descrição física e de conteúdo de materiais envolve processos genéricos que compõem a cadeia da informação (ou ciclo de vida da informação), cujos componentes são: criação, disseminação, organização, armazenamento e uso da informação. Compreende-se, portanto, como processos específicos de Organização da Informação a catalogação, a classificação, a indexação e a criação de resumos, que se configuram, até então, como disciplinas fundamentais da área de Biblioteconomia (JOUDREY, 2002, p. 93). De acordo com a definição de Bräscher e Café (2010), o principal objetivo do processo de Ol é possibilitar o acesso e o produto de seu processo descritivo é a Representação da Informação (RI).

Entre os produtos de RI desenvolvidos pelas bibliotecas estão: as linguagens documentárias, o desenvolvimento de bibliografias especializadas (ou ainda, pesquisas temáticas específicas), os catálogos (especializados e/ou não), as listas, os índices (sazonais, livros mais utilizados e por quem, ou ainda índices e mapeamento de citações e, mais recentemente, as altmetrics) e os mais variados tipos de serviços de referência.

Ainda, na pesquisa de Bräscher e Café (2010), quando as autoras realizaram o levantamento dos contextos de uso dos termos de Organização e Representação da Informação e do Conhecimento nas linhas de pesquisas dos programas de pósgraduação, descobriram que existem outros temas de pesquisa em Ol mais 
específicos como: análise de assunto, indexação para Internet e metadados. Outros programas ainda abordam estudos mais específicos como Arquitetura da Informação, Web Semântica e Ontologias.

$\mathrm{Na}$ análise dos resultados da pesquisa "Organização da Informação: uma análise conceitual' de Garrido (2011), foram recuperados 62 itens entre livros didáticos, artigos de periódicos e trabalhos publicados em eventos. A maior parte da produção foi proveniente dos Estados Unidos e de língua inglesa. Embora a pesquisa tenha buscado verificar na bibliografia processos como classificação, indexação e resumos, a parcela mais expressiva recuperada foi sobre descrição física de materiais, ou seja, catalogação, atingindo um total 77,41\% dos itens (48 itens), sendo o atributo de maior frequência. Uma das discussões analisadas também foi sobre 0 caráter ora prático, ora teórico do material recuperado.

Entre os autores anglófonos, encontrou-se uma discussão sobre a mudança de nome de algumas disciplinas como "Catalogação" e "Classificação" para que fossem simplesmente nomeadas disciplinas de "Organização da Informação", expandindo o conceito para que os estudantes apliquem seu conhecimento a diferentes situações em áreas correlatas, requerendo estudos como gestão do conhecimento e arquitetura da informação (BRUCE; MIDDLETON, 1996; VELLUCCI, 1996). O texto de Burke também aborda esta discussão:

Por fim, o aspecto cosmético da mudança de nome de Catalogação e Classificação para Organização da Informação foi visto como ato de valorização dos cursos das instituições ligadas à programas de LIS. Com o advento da World Wide Web, a organização da informação foi considerada importante para muitos campos, enquanto catalogação e classificação permaneceu algo pertinente apenas à comunidade biblioteca (BURKE, 2004, p. 224-225, tradução nossa).

Entretanto, ao se pensar em uma definição para o conceito de Organização da Informação na Biblioteconomia, compreende-se que esta definição permeie o que se entendeu por muito tempo como "processamento técnico" e, hoje, com as Tecnologias de Informação e Comunicação teve o seu escopo ligeiramente ampliado.

É importante ressaltar que, ao se tratar os conceitos de processamento técnico, leva-se em consideração ferramentas que foram desenvolvidas enquanto processos para solucionar problemas de organização no mundo físico - principalmente no que 
se refere ao espaço e tempo. No que era até então entendido como processamento técnico, em se tratando de bibliotecas físicas, conceitualmente existem quatro processos básicos na Biblioteconomia: classificação, catalogação, indexação e criação de resumos. Estas atividades são consideradas o núcleo da área de Biblioteconomia, pois a acompanham desde sua gênese e fazem parte primordial de sua causa.

Na Biblioteconomia, a Ol também se faz presente nos estudos e discussões teóricos sobre os processos tradicionalmente utilizados nas bibliotecas (catalogação, classificação, indexação e criação de resumos) e seus produtos (controle bibliográfico e catálogos, números de chamada, índices, etc.). O tratamento técnico de recursos informacionais está previsto na Classificação Brasileira de Ocupações $(\mathrm{CBO})^{4}$, referente ao cargo de bibliotecário:

Disponibilizam informação em qualquer suporte; gerenciam unidades como
bibliotecas, centros de documentação, centros de informação e correlatos,
além de redes e sistemas de informação. Tratam tecnicamente e
desenvolvem recursos informacionais; disseminam informação com o
objetivo de facilitar o acesso e geração do conhecimento; desenvolvem
estudos e pesquisas; realizam difusão cultural; desenvolvem ações
educativas. Podem prestar serviços de assessoria e consultoria (CBO, 2019,
grifo nosso).

Na Ciência da Informação, o foco volta-se para cadeias de informação como um todo, a partir de perspectivas em análises de domínios, em contextos mais específicos ou gerais.

Em um estudo concluído em 2011, onde foi pesquisado o tema de Ol nas teses e dissertações produzidas pelos programas de pós-graduação em Ciência da Informação no Brasil, levou-se em consideração que a diversidade das Áreas de Concentração e Linhas de Pesquisa nos diferentes cursos de pós-graduação poderia nos auxiliar a inferir sobre a variedade na temática de Ol na produção de teses e dissertações.

A partir de uma perspectiva da Cl, Svenonius (2000) em seu livro "Intellectual Foundations of Information Organization" trabalha a partir de uma perspectiva 
filosófica, adotando um quadro de trabalho conceitual, questionando cada uma das partes a serem tratadas em OI: filosofia de sistemas, da ciência e da linguagem. $O$ processo de Ol é compreendido como o uso de uma linguagem especial de descrição, chamada linguagem bibliográfica e, para ser efetivo, deve se basear em seus fundamentos intelectuais, que consistem de: ideologia formulada a partir de propósitos, formalização dos processos, conhecimento adquirido por pesquisa e problemas chave que precisam ser resolvidos. Para Svenonius:

O objetivo essencial e definitivo de um sistema para organização da informação, então, é trazer essencialmente informações similares juntas e diferenciar o que não é exatamente semelhante. Designar um sistema para atingir esse propósito é sujeito a várias restrições: deve ser econômico, deve manter continuidade com o passado [...] e deveria tirar pleno proveito das tecnologias atuais (SVENONIUS, 2000, p. 11-12, tradução nossa).

Em se tratando de produção de teses e dissertações sobre Ol no Brasil, a partir da $\mathrm{Cl}$, foi possível extrair dos materiais recuperados informações que indicaram tendências de estudos na área. Foram recuperados 112 itens (83 dissertações e 29 teses), entre os anos de 1987 a 2011, sendo que a recuperação mais expressiva de materiais sobre esta temática foi entre os anos de 2005 a 2010. No tratamento dos resultados, a análise de conteúdo foi realizada de modo a organizar 5 categorias de acordo com os temas abordados:

Quadro 1 - Frequência dos termos de acordo com as categorias.

\begin{tabular}{l|l}
\hline \multicolumn{1}{c|}{ Categorias } & \multicolumn{1}{|c}{ Termos Mais Frequentes } \\
\hline $\begin{array}{l}\text { Objetos de } \\
\text { Estudo }\end{array}$ & $\begin{array}{l}\text { Fotografia (6); Web (6); Hipertexto (3); Museu (3); Categoria (2); } \\
\text { Documentação (2); Metadado (2); BDTD (2); }\end{array}$ \\
\hline $\begin{array}{l}\text { Áreas do } \\
\text { Conhecimento }\end{array}$ & $\begin{array}{l}\text { Ol (26); Recuperação da Informação (10); OC (10); RC (10); RI (10); Cl } \\
\text { (5); Biblioteconomia (2); Representação Documentária (2); }\end{array}$ \\
\hline $\begin{array}{l}\text { Teorias, } \\
\text { Abordagens e } \\
\text { Metodologias }\end{array}$ & $\begin{array}{l}\text { Análise Documentária (4); Terminologia (4); Tratamento temático da } \\
\text { Informação (4); Método Analítico-Sintético (3); }\end{array}$ \\
\hline $\begin{array}{l}\text { Processos } \\
\text { Produtos }\end{array}$ & $\begin{array}{l}\text { Indexação (10); Classificação (5); Catalogação (3); Ambiguidade (2); } \\
\text { Ontologia (19); Linguagem Documentária (6); Taxonomia (5); Tesauro } \\
\text { Metodologia (2); da Informação (2); Linguagem de Indexação (2); }\end{array}$
\end{tabular}

Fonte: Garrido (2011). 
Reavaliando os termos recuperados, é possível compreender que não apenas a Ol se encontra consolidada nos últimos anos como Área do Conhecimento em estudos de pós-graduação na $\mathrm{Cl}$ do Brasil, como também suas variáveis, entre elas a RI, OC, Representação do Conhecimento e Documentária. O tema de Ol se aprofunda na medida em que é ambivalente: é possível compreendê-lo e estudá-lo profundamente, tanto em sua teoria (como observamos nas frequências das categorias 'Áreas do Conhecimento' e 'Teorias, Abordagens e Metodologias'), quanto em aspectos mais práticos (Objetos de Estudo, Processos e Produtos).

Até o ano de 2011, estudos sobre Ontologias e sua relação com as novas tecnologias computacionais e em como isso se relacionava com a OI, eram uma tendência factível. E, embora os estudos apresentados fossem um tanto quanto generalistas em sua base, a tendência era de desenvolver-se em sua especificidade ao longo do tempo, com estudos de Ol sobre fotografia, web, linguagem documentária e arquitetura da informação.

\subsection{Organização do Conhecimento (OC)}

Verifica-se que os processos de classificação e categorização tem intersecção com as áreas de Ol e Organização do Conhecimento (OC). No entanto, os atos de classificar e categorizar também têm suas distinções. Em seu artigo "Classification and Categorization: a Difference that Makes a Difference", Jacob (2004) procura esclarecer as diferenças entre os processos de classificação e categorização:

Enquanto a classificação tradicional é rigorosa na medida em que determina que uma entidade é ou não é um membro de uma classe particular, o processo de categorização é flexível e criativo e desenha associações nãovinculantes entre entidades - associações que são baseadas não em um conjunto de princípios pré-determinados mas no simples reconhecimento de similaridades que existem através de um conjunto de entidades. Classificação divide um universo de entidades em um sistema arbitrário de classes mutuamente exclusivas e não-sobrepostas que são arranjadas dentro do contexto conceitual estabelecido por um conjunto de princípios estabelecidos (JACOB, 2004, p. 12). 
Para os efeitos deste trabalho e deste capítulo, foi analisado apenas o processo de classificação. Compreende-se que a OC opera no mundo através de Sistemas de Organização o Conhecimento (SOC), que podem ser exemplificados através de ferramentas modernas tais como a Classificação Decimal de Dewey (CDD) e a Classificação Decimal Universal (CDU), até outros tipos de ferramenta utilizadas pelas ciências naturais, a exemplo do sistema de classificação dos seres vivos, desenvolvido por Lineu.

Há, entanto, uma sinonímia com o termo "classificação" quando utilizado em diferentes contextos. A "Classificação" no contexto de OC designa a criação de uma abstração para classificar o mundo e consequentemente a criação de um SOC; Enquanto em um contexto de OI, "Classificação" significa o próprio ato contínuo de classificar um item (ou verificar sua alocação) em um SOC já pré-definido e/ou estabelecido.

Mai (2016, p. 327) compreende que o objetivo dos bibliotecários tinha um propósito diferente dos pensadores filosóficos de classificação, e as questões que se empenhavam em resolver tinham foco em questões práticas. Para o autor é difícil manter diálogo entre pesquisa e prática, uma vez que se tratam de diferentes linguagens onde a pesquisa e a academia se preocupam "com a descoberta de novos insights e conhecimento sobre organização do conhecimento, a prática parece preocupada com as tarefas práticas de projetar, implementar e manter sistemas de organização do conhecimento já existentes".

Diferentemente da materialidade da OI, a Organização do Conhecimento (OC), conforme descrevem Bräscher e Café (2010, p. 92), envolve "o mundo da cognição, ou das ideias, cuja unidade elementar é o conceito". As autoras observam que os Sistemas de Organização do Conhecimento se tratam de sistemas conceituais que "representam determinado domínio por meio da sistematização dos conceitos e das relações semânticas que se estabelecem entre eles" (BRÄSCHER; CAFÉ, 2010, p. 96).

Essa desambiguação evidenciada se faz fundamental para que se diferencie o entendimento de processos operacionais e, assim, distingui-los de processos filosóficos, de pensamento e visão de mundo, embora, no campo da $\mathrm{Cl}$, eles sejam muito interdependentes. 
A Organização do Conhecimento, por sua vez, visa à construção de modelos de mundo que se constituem em abstrações da realidade. [...] a Representação do Conhecimento, que se constitui numa estrutura conceitual que representa modelos de mundo, os quais [...] permitem descrever e fornecer explicações sobre os fenômenos que observamos. (BRÄSCHER; CAFË, 2010, p. 6-7, grifo nosso).

Através dos artigos desenvolvidos por Olson (2002), García Gutiérrez (2006) e Mazzocchi (2013) é possível compreender o tema de OC transversalmente, abordado por autores de origens distintas, através de perspectivas diferentes, no entanto, com conclusões que conversam entre si.

Olson (2002), bibliotecária e norte-americana, também trata sobre classificação e universalidade em seu artigo, suas aplicações e construção. A autora compreende a natureza lógica e hierarquizada do tipo de classificação aristotélica, ao mesmo tempo em que também questiona a pretensão humana (e principalmente ocidental) de se fazer crer que existe apenas uma classificação possível capaz de abranger todo o conhecimento humano.

Para Olson (2002, p. 389), a regeneração da classificação se daria justamente através do aumento da transgressão de limites impostos, aumentando a sua complexidade, quanto pela amplificação de contexto, adicionando valor ao que já existe uma vez que "a estrutura de classificação constrói os significados do que classificamos. Se usarmos o poder da classificação conscientemente podemos aumentar os significados, ao invés de compartimentalizar conceitos".

Mazzochi (2013), biólogo e filósofo italiano, argumenta em favor do pluralismo na classificação, que pode ser justificado em termos do que é culturalmente possível. $\mathrm{O}$ autor compreende como as figuras da árvore e da rede enquanto rizoma (conceito de Deleuze e Guattari, de 1987) têm sido usados para representar diferentes tipos de pensamentos e visões sobre conhecimento. Essas estruturas de pensamento e de organização se fazem fundamentais no desenvolvimento da ciência, pois, segundo o autor:

Ao invés de buscar por um ponto fundamental de observação, cientistas precisam explorar pontos de vistas múltiplos (e ainda potencialmente compatíveis) por exemplo, perspectivas disciplinares, que podem complementar uma a outra quando descrevem ou explicam um certo fenômeno ou sistema (MAZZOCHI, 2013, p. 369). 
No entanto, Mazzochi adverte que reconhecer a importância de descrições múltiplas não implica que todas sejam possíveis ou tenham valor plenamente equivalente. $\mathrm{O}$ autor trata de forma cronológica a epistemologia do pensamento classificatório, partindo de uma suposta evolução, que se iniciaria no modelo aristotélico e seus princípios, perpassaria pelas classificações univocais e necessárias - com hierarquias múltiplas apenas concebidas a partir do indivíduo - até chegar no chamado pluralismo antológico ou ainda, realismo promíscuo de Dupre, onde não haveria modo único de classificação.

Este último se equipara muito ao conceito rizomático e de rede que, de acordo com o autor, é um tanto paradoxal e contraditório:

Pensamento rizomático e a cultura de rede parecem estar refletidos um no outro. No entanto, paradoxalmente, a rede age como uma poderosa máquina de padronização em diferentes níveis. Isso sugere que ainda vivemos em um mundo que é resultado do nosso histórico cultural e que o rizoma segue o mesmo padrão de desenvolvimento que a árvore (MAZZOCHI, 2013, p. 370).

$\mathrm{Na}$ literatura da área de Comunicação, ainda são realizadas muitas comparações entre o conceito de rizoma e o conceito de hipertexto ou hiperlink para a web. No entanto, o conceito de hiperlink se relaciona e faz parte da cultura do estilo de rede, mas o que é veiculado através do seu conteúdo poderia ser entendido como rizomático, dependendo do contexto.

Já García Gutiérrez trata a questão de classificação de modo iconoclasta, questionando a legitimidade de determinadas representações de organização do conhecimento: "conhecimento para que e para quem?". Para o autor, classificar - ou ainda, de acordo com a sua visão, desclassificar - é um ato intrinsecamente político, ético e principalmente que envolve dominância e resistência:

A expansão do digital e da tecnocultura obriga, sem dúvida, a um exercício de pluralismo ético, que consiste em criar ferramentas que não apenas auxiliem na organização dos "conhecimentos dominantes", mas, especialmente, que promovam a resistência dos conhecimentos considerados subalternos. Esses conhecimentos, culturas e memórias estão ameaçados por projetos globalizantes de substituição e, consequentemente, não Ihes resta outra saída senão apropriarem-se do digital como única possibilidade de autodesenvolvimento (devolver a diversidade com as tecnologias unificantes, dirá James Clifford). Incorporar nas redes digitais os 
conhecimentos excluídos dos fluxos em que transitam os conhecimentos dominantes: essa seria, resumindo, uma função tecnopolítica da epistemografia interativa (GARCÍA GUTIÉRREZ, 2006, p. 105).

Neste sentido, García Gutiérrez trata da abertura de um espaço para que o estudo epistemográfico possa ser viável. Pelo que foi compreendido, este estudo pode existir de forma concomitante à epistemologia, sem substituí-la completamente. Embora tenha sido criada a partir de contextos da Museologia e da Biblioteconomia, a epistemografia integrativa tenta livrar-se não destas áreas - suas práticas e seus processos - em si, mas de sua orientação positivista.

No entanto, imaginamos que se torna um verdadeiro desafio para 0 epistemógrafo tornar-se efetivamente, ao longo do percurso de uma só vida, um profissional verdadeiramente nexialista, conseguindo abarcar diferentes tipos de conhecimento em sua bagagem história sem, no entanto, sobrecarregar-se.

A Organização do Conhecimento se encontra de forma transversal nos três artigos de autores completamente distintos, uma vez que Olson investiga as estruturas sob as quais se erguem as Organizações do Conhecimento e suas representações, questionando detalhadamente suas razões de ser - evidenciando a sua diversidade. Mazzocchi pesquisa e argumenta em favor do pluralismo compreendendo que a classificação pode sofrer variações de acordo com seu contexto culturalmente possível. E García Gutiérrez destaca esse pluralismo e vai além, propondo uma desconstrução da classificação enquanto a conhecemos e subvertendo a Organização do Conhecimento através de sua epistemografia interativa.

Em se tratando de Organização do Conhecimento, embora estejamos inseridos em um contexto ocidental, onde a predominância é de um sistema lógico aristotélico, hierarquizado e positivista, onde existiu (e existe ainda, em certa medida) a ideia de uma grande unificação e centralização do conhecimento em um só lugar, é interessante perceber que o contexto e as diferentes culturas podem adicionar complexidade ao ato dito "natural" de classificar o mundo e as coisas.

A importância do papel da cultura na Organização do Conhecimento concerne questões de ordem ética, política e criativa, uma vez que essas estruturas e sistemas 
são criados para a representação de conceitos abstratos, possuindo, no entanto, muito frequentemente implicações e consequências um tanto quanto tangíveis e reais.

No próximo capítulo, busca-se compreender os contextos de cultura e informação a partir de três perspectivas: o entendimento do papel da cultura na Organização do Conhecimento, a variável da Cultura Digital e seu impactos na forma de observar o mundo como o conhecemos e da questão de Arquitetura da Informação e Experiência do Usuário como estruturas narrativas por onde navegamos, que são selecionadas especificamente de acordo com o propósito ou intenção de seu contexto, seja ele mercadológico ou de aprendizagem. 


\section{A QUESTÃO DA CULTURA NA ERA DA INFORMAÇÃO}

A cultura e seu papel, muitas vezes foi entendida como algo à parte da Biblioteconomia - o enfoque particular na área sempre foi outro, bem mais tecnicista e, principalmente, voltado para a OI e para a gestão. Explorar a questão da cultura na Era da Informação, não como pano de fundo, mas como sua causa e propósito maior é tratar de temas que são complexos em relação à própria Organização da Informação e do Conhecimento, mesmo porque, como verificado no capítulo anterior, ambos os conceitos trabalham de forma interdependente dentro da própria Biblioteconomia e também na área de Ciência da Informação.

Este capítulo vai explorar principalmente a questão cultural na Era da Informação. No Capítulo 3, compreendeu-se o ponto de partida a partir de estudos principalmente realizados durante a graduação em Biblioteconomia. Este capítulo aborda a questão da organização enquanto fenômeno cultural e subjetivo, a partir de conhecimentos adquiridos ao longo da Pós-graduação em Ciência da Informação.

Também compreende o tempo em que estamos, considerando os aspectos e as variações entre os tipos de organização do mundo físico e do mundo digital, como as suas zonas cinzentas e aspectos híbridos. É preciso compreender como a cultura nos leva a entender a curadoria digital como um possível intermediário e como isso tem se estabelecido atualmente.

\subsection{A organização enquanto fenômeno cultural}

Para Hope Olson (2002), a classificação, além de ser inerente a ação humana, trata-se de uma atividade universal e culturalmente situada, que segue linhas de força e poder político. A autora nos oferece exemplos de que modos um esquema de classificação do conhecimento pode promover a compartimentalização, através de sintomas na Classificação Internacional de Doenças (CID) utilizado pela Organização Mundial da Saúde e no caso do Apartheid na África do Sul onde isso ocorreu pela via da segregação. Olson não apenas realiza uma crítica das possíveis aplicações da 
classificação, mas, principalmente questiona as conjecturas subjacentes da própria estrutura classificatória, dos seus porquês de existência.

Como as classificações também tratam de possibilidades de materialização de conceitos e abstrações, para "definir a classificação como objeto de limitação pelo do qual as sociedades se encontram devemos levar em consideração a função representativa da classificação" (OLSON, 2002, p. 379). Uma classificação não é somente um conjunto de escaninhos feitos meramente para acomodar o que quer que esteja sendo organizado, mas é um sistema para que determinado universo seja devidamente representado.

Olson trata de alguns princípios básicos da classificação como foi naturalizada no ocidente tais como: ser universal - definindo assim limites e implicando, por sua vez, falta de limitação - bem como possuir uma suposta neutralidade e lidar com um território geográfico finito.

Isso nos leva aos atuais problemas em classificação. A classificação, por sua vez, pode ser entendida como um mapa, como a tentativa de um mapeamento do que existe: e como em todo mapa, existem impossibilidades, limites e também inconsistências de indexadores através do tempo, um problema que também é abordado por Buckland (2007). O problema das interpolaridades na classificação, ou ainda, o cruzamento de fronteiras traz à tona a questão da mediação deste tipo de representação, de sua própria possibilidade. Não há neutralidade, isenção ou imparcialidade e muito frequentemente "o critério para a criação de uma classificação indicará suas entrelinhas ideológicas” (OLSON, 2002, p. 384).

No artigo "Marginalização e exclusão: desvendando viés sistêmico de classificação" de Mai (2016, p. 327, tradução nossa), ao encontro de Olson, compreende que "pode ser difícil identificar tais marginalizações e exclusões de grupos de pessoas porque as classificações bibliotecárias geralmente refletem uma posição cultural mainstream". O principal desafio, neste caso, é que este comprometimento com a neutralidade esconda os viéses de classificações e dificultem as conversas sobre os efeitos culturais de classificações que marginalizam e excluem visões fora da corrente de pensamento mainstream política, social e ética (MAI, 2016, p. 327). 
Em relação a construção cultural da classificação, no ocidente se compreende como naturalizada a classificação aristotélica e hierarquizada, sendo deliberadamente preteridas classificações de outras culturas, como os exemplos oferecidos de classificação taoísta, chinesa e indígena, onde a ambiguidade é compreendida como elemento natural da classificação e não algo a ser evitado ou combatido. Esta questão da classificação como ferramenta de autoridade também é colocada em evidência, pois as mais reconhecidas estruturas de classificação estão ligadas a grandes instituições e, hoje em dia, a grandes empresas.

Mazzochi (2013) investigou de que modos o pensamento classificatório depende diretamente do background epistemológico no qual foi desenvolvido. Em seu artigo, analisa como as figuras da árvore e da rede enquanto rizomas têm sido utilizadas para representar diferentes tipos de pensamento e visões sobre conhecimento. Descrevendo o conceito de árvore, partindo do princípio aristotélico, Mazzochi encontra alguns elementos para designar esta representação do conhecimento. A figura da árvore incorpora os pressupostos que: a) Trata-se de uma ordem de mundo finita, hierárquica e lógica; b) Uma realidade objetiva, que independe de nós; c) Um conjunto único de propriedades essenciais, logo se trata do único jeito de organizar o mundo em conjuntos; d) Epistemologicamente, atinge o ponto arquimediano do qual se vê a realidade "como ela realmente é".

Enquanto as árvores não possuem ciclos sendo estruturas fechadas, os conceitos de rede e rizoma trabalham com loops complexos, cada um a seu modo. Embora de acordo com Mazzochi os conceitos de rede e rizoma sejam distintos, ambos possuem algumas características comuns, tais como: a) Laicidade do Conhecimento e iluminismo e projetos enciclopédicos; b) Propósito emancipatório com objetivo de nos deslocar das superestruturas lógico-linguísticas dominantes (e paralisantes), que previnam o livre movimento (e recombinação criativa das ideias); c) Pensamento: singularidade, multiplicidade, diversidade, diferenças. Referente à sua própria estrutura, os conceitos de Rizoma e Rede tem suas distinções.

O Rizoma pode ser definido como um objeto topológico de um ponto de vista matemático, isto é, um tipo de gráfico com nós e conexões onde principalmente a indeterminação e fragmentação de suas superfícies são características em seu contexto de pós-modernismo. Já a Rede se trata de uma estrutura com começo, meio 
e fim, inserida em sistemas abertos e participativos, com controle distribuído e ampla capacidade de adaptação e evolução, tendo como principais características a conectividade, unidade, complexidade e construtivismo. Ao tratar das possibilidades de Sistemas de Organização do Conhecimento, estas formas adaptáveis e abertas, seriam mais permissivas em relação a uma mediação que visa e prioriza a discussão e participação, em detrimento do controle.

García Gutiérrez (2006), pesquisador espanhol, também aborda a questão dos viéses e do pluralismo na classificação, no entanto defendendo suas perspectivas de um ponto de vista mais autoral. Sua proposta é a de substituição da epistemologia contemporânea enquanto a conhecemos, pelo que chama de epistemografia interativa e a sua principal intenção é a de justamente se fazer presente em lugares de exclusão.

Quando ele usa a expressão "cientificamente favelados" no título de seu artigo, o autor se posiciona, referindo-se à um conhecimento que é marginalizado pela academia no geral e não é incorporado em absoluto por suas redes, que frequentemente se limitam a transmitir exclusivamente conhecimentos dominantes. $O$ autor acredita que:

Nesse sentido, a epistemografia explora e fornece ferramentas
independentes da epistemologia, autorevelando sua presença e evitando
envolver-se nas práticas de auto-organização que propõe, categorias
polissêmicas e porosas, indagações intersticiais (in-betweenness),
hierarquizações autodesmontáveis, conceitos abertos e dinâmicos, relações
interconceituais polivalentes e inclusive contraditórias, pluralismo lógico e
racionalidades heterogêneas e mediadas culturalmente, favorecimento de
hibridações, busca de dissenso e da diversidade, antes que de consenso e
unificação (GARCíA GUTIÉRREZ, 2006, p. 105-106).

O artigo de García Gutiérrez, por ser essencialmente filosófico e tratar de temas bastante abstratos e conceituais, é uma leitura desafiadora, no qual se faz necessário rever os conceitos e compreendê-los em sua totalidade, mesmo - e principalmente em seu paradoxo e sua contradição. O autor acredita na promoção do dissenso para o aumento do diálogo e, consequentemente, de maior produção de conhecimento. Este tipo de apropriação do conhecimento, realizado pela via da cultura, pode ser viabilizado através da mediação dos saberes, da ampliação dos espaços para promoção dessa nova sociedade global, seja ela física ou digital. 
Ao longo do artigo, García Gutiérrez não mira exclusivamente em nenhum tipo de ferramenta de Organização do Conhecimento em específico, tratando o tema de uma forma um tanto quanto abstrata. Ao modo de Feyerabend e o seu "Anything goes", García Gutiérrez (2006, p. 104) acredita que a ciência também pode ser uma história "repleta de irrelevâncias, de felizes inconsistências, de oportunos esquecimentos e, especialmente, de imprevisíveis contradições que criam, com uma força motriz sempre negada, a poderosa máquina do conhecimento". E são nessas lacunas, não evidenciadas e frequentemente negligenciadas pela epistemologia tradicional, onde a mágica do conhecimento humano pode acontecer e se desenvolver.

Durante o percurso de compreender a organização da informação e do conhecimento, a partir de uma perspectiva cultural mais abrangente, foi possível relacionar alguns questionamentos em relação a Curadoria. Neste sentido, pôde-se investigar o tema se atentando à possível verificação das seguintes possibilidades: a) De que modo a cultura e a organização da informação e do conhecimento tem participação no desenvolvimento de curadorias?; b) Em quais sentidos a curadoria pode se posicionar enquanto espaço de desintermediação da informação?; c) Quais as tendências de curadoria em diferentes culturas, seus desenvolvimentos e possíveis tensões?

\subsection{Do mundo físico para o digital}

Martel (2015) no capítulo Smart Curation de seu livro Smart, começa a tratar do assunto de plataformas digitais na famosa livraria argentina El Ateneo. Isto é significativo de nossa época, uma vez que esta mesma livraria teve seu espaço ressignificado várias vezes ao longo dos anos, desde a época do rádio, do cinema, até se tornar de fato uma livraria nos dias de hoje. Mas, mais que uma livraria, podese dizer que o El Ateneo se tornou um tipo de espaço de convivência, o que poderia, ainda, ser compreendido como um espaço de mediação.

Algo semelhante ocorre quando se observa os produtos que existem no mundo físico, mas que agora incorrem em possibilidades de utilização em diferentes 
plataformas eletrônicas, podendo tanto ser oferecidos digitalmente (pdfs, e-books, etc), quanto por meio da Internet (publicações em blogs e outras plataformas de compartilhamento de conteúdo). Isto faz parte, principalmente, da mudança de mentalidade da web 1.0 para a web 2.0, em que ainda nos encontramos.

A mudança das plataformas de produtos culturais para serviços e assinaturas em streaming é considerada por Martel uma "evolução" - com todo o peso que esse conceito carrega em si - e não uma característica de um contexto que ainda se encontra em desenvolvimento. Provavelmente a tentativa do autor, enquanto jornalista, tenha pretendido ser a de isenção e imparcialidade, no entanto, o interesse em relação ao poder estabelecido das grandes empresas ficou em maior evidência.

\begin{abstract}
A música deixa de ser um objeto sob a posse de alguém para se tornar algo a que se tem "acesso" e pode ser ouvido (...) a partir de uma única assinatura genérica. (...) De que serve continuar a tê-los numa "biblioteca", palavra que, segundo alguns, já pertence ao passado? Ao invés de se apropriarem desses objetos culturais, num espírito de acumulação burguesa, as pessoas se limitarão a ter acesso a eles: a assinatura, e não mais a propriedade, seria então o futuro da cultura (MARTEL, 2015, p. 272).
\end{abstract}

O recorte de Martel, no caso de consumo individual, e se tratando de usuários e clientes em um contexto mercadológico, o ato de colecionar produtos - ao invés de utilizar de um serviço de streaming, por exemplo - trata-se de um "espírito de acumulação burguesa". No entanto, pouco ou quase nada é dito - ao menos não no capítulo de Smart Curation - quando se trata de grandes corporações que, em contrapartida à utilização desses serviços, coletam e acumulam dados pessoais de seus utilizadores - o conhecido Big Data - com possibilidade de revenda e lucro ou, até mesmo, para maior previsibilidade de tendências futuras de consumo, mediante contrato.

Martel (2015), que é jornalista e francês, escolhe evidenciar uma visão um tanto quanto pessimista do futuro, na qual suspeita que a convergência chegará a tal ponto onde tudo será substituído pelo digital e o mundo será plenamente imaterial - o que é um tanto utópico. "Botbol (CEO da Taringa, comunidade virtual argentina) está convencido de que a internet vai arrastar tudo em sua passagem" diz o autor, que poderia ser enquadrado em uma visão mais apocalíptica que integrada. No entanto, é possível realizar o questionamento: pessimista e apocalíptico para quem? E em 
relação ao quê? Este posicionamento é útil no sentido de que serve também para ilustrar o quão insidiosas estas tecnologias já são em nossas vidas diárias:

\begin{abstract}
A virada digital já está aí: considerável, total, irreversível. A questão é antes saber de que maneira a Internet vai alterar a situação, até que ponto, e o que restará das obras, da hierarquia cultural, do jornalismo crítico e do modelo econômico no fim dessa revolução que está apenas começando (MARTEL, 2015, p. 257-258).
\end{abstract}

No entanto, quando se trata de cultura digital, é importante se ter em mente que em nossa época atual ainda existe um hibridismo que implica numa "fase de transição" - por falta de termo mais adequado - em que nos encontramos. Embora muitos documentos atualmente sejam born digital, ainda estamos longe de uma realidade digitalizada em sua totalidade, ampla e irrestritamente em todos os aspectos. Esse deslocamento de plataformas é cultural, não é algo à parte, mas algo intrínseco aos processos e desenvolvimentos do mundo.

Com a popularização da internet e dos recursos web, serviços de informação online se proliferaram nos últimos anos. A disponibilidade de serviços como bases de dados, websites e blogs, fez com que as pessoas tivessem mais facilidades na comunicação e pudessem se organizar em rede, estruturando e gerenciando sua própria produção online. Isso fortaleceu o desenvolvimento de novas ferramentas e novos negócios e, principalmente, desenvolveu comunidades em torno de temas de interesse.

Tanto a produção de conteúdo quanto de metadados atualmente não é mais derivada exclusivamente de profissionais ou criadores de conteúdo especializados, mas frequentemente dos próprios usuários de informações. Portanto, o estudo destes processos se faz pertinente no âmbito da Ciência da Informação, pois sua natureza e algumas de suas características vão diretamente de encontro aos mais conhecidos princípios e teorias de organização e de classificação - e ainda assim, é possível observar que este modo de organização da informação persevera e prospera em ambientes web.

A ideia central de Smart Curation (2015) parece abordar a perspectiva da nova economia de produtos enquanto serviços, entendendo a imaterialidade como algo não 
só natural como desejado. De acordo com Botbol "as indústrias criativas pensam a internet como uma ferramenta de distribuição de seus produtos [...] embora ela também seja, talvez mais que tudo, o lugar de produção de uma nova cultura". Os prosumers, consumidores ao mesmo tempo em que são produtores para a web são as pessoas que alimentam essa indústria, através de compartilhamento, criação e recriação de novos conteúdos.

Mas, ao que tudo indica, o mundo imaterial ainda é um tanto quanto dependente do mundo real. Isso fica claro com os exemplos para a estratégia digital para San Francisco Symphony, que tem como mecenato grandes empresas de tecnologia de ponta. De acordo com John Kieser, a preocupação com o público ainda é latente uma vez que "se não formos capazes de criar uma conversa em torno dela nem de ter uma verdadeira presença online, talvez não consigamos mais convencer o público a se deslocar fisicamente até um auditório" (apud MARTEL, 2015, p. 260, grifo nosso).

Ao tratar da indústria da música, Martel cita o exemplo de Jad Choueiri, o que remete a um outro exemplo similar, que seria o da artista Amanda Palmer, que publicou a história da sua carreira musical no livro The Art of Asking (2014). Para muito além da questão da conversa, Palmer detalha em seu livro como se deu a criação de sua fanbase, show a show, em meet and greets onde conheceu seus fãs um a um. Além da questão de desintermediação que ocorreu em sua carreira, ao abandonar o selo com o qual tinha contrato e seguir de modo independente via crowdsourcing pelo Kickstarter, a autora se foca muito na conexão direta que faz com os fãs e ressalta a importância do desenvolvimento direto de uma comunidade forte através disso.

Enquanto no caso do Jad Choueiri, a preocupação parecia ser de arrumar algum modo de as pessoas pagarem por suas músicas e por seu conteúdo, Palmer é bem enfática em seu Ted Talk, quando afirma ao final de sua apresentação que "acredito que as pessoas tem ficado obcecadas com a pergunta errada que é "como fazemos as pessoas pagarem por música?". E se começássemos a perguntar "como nós deixamos as pessoas pagarem por música?"”5 (PALMER, 2013).

Martel (2015, p. 276) afirma que "a indústria tem todo interesse em adotar a 
web, pois através dela pode ganhar não só financiamentos como também diversidade", e acontecerá porque os artistas que souberem lidar com esta nova economia não se sentirão mais pressionados por mediadores como selos, gravadoras e empresários. No entanto, o foco de Martel foram as paradas de sucesso e o mainstream americano, voltado para uma cultura de massa, enquanto Palmer aborda, a partir de uma perspectiva de uma cultura underground, a partir de suas próprias experiências e com mindset voltado para um nicho específico.

O interessante dessa perspectiva é que o autor entende que as pessoas deixarão de "colecionar" produtos e passarão a utilizar apenas serviços, ilustrando uma certa "morte do colecionismo" ao mesmo tempo em que, em ambiente web, fazse necessário, mais do que nunca, realizar uma boa criação de repertório, um levantamento de referências com base na confiabilidade e, enfim, organizá-los de alguma forma. Desde a seleção, nomeação e classificação de conjuntos e/ou itens, a prática do colecionismo permanece em voga, tendo sido modificada apenas em seus meios e mediações. Para Goldsmith (2011, tradução nossa) "o advento da cultura digital tornou cada um de nós arquivistas inconscientes. Do momento que utilizamos o comando de "salvar como" quando estamos compondo documentos eletrônicos, nossos impulsos arquivistas começam". Ou seja, trata-se de um paradoxo: o colecionismo está morto e, no entanto, está mais vivo do que nunca - ele apenas se deslocou para um outro ambiente, uma outra proposta.

Imagina-se que, tal qual o final do livro Fahrenheit 451 de Ray Bradbury (2009), uma distopia onde todos os livros físicos são eliminados por uma força maior e os personagens ao final da história mantém os conteúdos guardados apenas na memória e os repassam através da tradição oral, o colecionismo está se tornando e se tornará cada vez mais não só imaterial, como um tanto quanto místico: algo a ser compartilhado de forma cada vez mais primitiva (presencialmente, oralmente), no entanto, contando com todas as possibilidades e facilidades tecnológicas praticamente como o exemplo que Amanda Palmer descreve em seu livro, The art of asking.

As pessoas se preocupam com o conteúdo e com a forma de apropriação deste conteúdo: o colecionismo de sensações provocadas pela experiência de determinado serviço. E isso já tem sido estudado por áreas como a Customere a User Experience. 
Essa experiência pode apelar para várias questões humanas como os sentimentos, a sensação de conexão a algo maior e, principalmente, à nostalgia.

Wittgenstein (1968) dizia em seu Tractatus que "os limites de minha linguagem são os limites do meu mundo". É preciso, então, questionar o que se perde e o que se ganha não só em termos mercadológicos e sociais mas principalmente cognitivos com essa transição da cultura de produtos para a de serviços.

Subtende-se com a citação do autor que o conceito de biblioteca possa ser um tanto quando limitado e reducionista, uma vez que bibliotecas são muito mais do que apenas desenvolvimentos de coleções. Se o acesso é ilimitado, mas imaterial, faz-se pertinente questionar como ficam as questões de desenvolvimento pessoal de repertório (afinal, as pessoas precisam de alguma base e de referências), bem como a questão dos afetos e das memórias.

Martel compreende que grandes empresas de comunicação e entretenimento como o Youtube (líder do streaming gratuito, pertencente ao Google) e Spotify (líder de mercado da música por streaming) são o futuro dos serviços culturais, oferecidos em nível global. O autor atenta para o modo de consumo "all you can eat" nessas plataformas e entende como possível solução para este tipo de impacto uma mediação através da recomendação, seja através de uma curadoria humana ou híbrida:

Quando a cultura, ainda ontem constituída essencialmente de "produtos
culturais", passa do analógico ao digital e se torna uma soma de "produtos
culturais", faz-se indispensável recorrer aqueles que recomendam. Caso
contrário, como abrir caminho no catálogo do Spotify, com mais de vinte e
cinco milhões de títulos? Como se achar em meio às trezentas horas de
vídeos incluídos no YouTube a cada minuto? A oferta é de tal maneira
ilimitada que chega a ser vertiginosa. A expressão all you can eat, usada às
vezes, é sintomática. Como nos restaurantes chineses onde é oferecido esse
tipo de cardápio, pode-se comer à vontade, à saciedade - e às vezes, até a
indigestão (MARTEL, 2015, p. 291).

Essa indigestão à qual Martel se refere, trata-se não apenas do consumismo desenfreado em si, mas também da própria forma que ele é realizado. O consumidor da Internet, justamente por estar lidando com algo imaterial, é bastante exigente. Tanto para a forma quanto para o conteúdo, as pessoas precisam se empanturrar de "experiências" e tudo precisa ser fascinante. Não há mais tempo ou paciência para 
aprendizado ou para encontrar vivências no ordinário, vide a referência sintomática do livro sobre usabilidade "Don't make me think" ("Não me faça pensar", em tradução livre) do autor Steve Krug (2005). Para este tipo de persona, o importante é o obter enquanto cliente, não o ser integralmente enquanto humano.

A questão que muitas vezes se coloca é que quando lidamos com o digital e principalmente com ambiente web, uma série de outras questões que vão além da documentação e de outros problemas enfrentados por uma biblioteca física vêm à tona, tais como: a diferença entre documentos digitalizados e born digital, entre dados estruturados e não-estruturados, entre o estudo de métricas, altmetrics e analytics e seus objetivos, entre curadoria da informação digital e curadoria para web. Todos estes itens tratam de informação em um contexto independente da biblioteca física e, no entanto, com temas extremamente profícuos para a Ciência da Informação.

No entanto, é preciso analisá-los de forma a não replicar um padrão que funciona em uma realidade física diretamente para a realidade digital. Alguns processos geralmente são somente replicados para o digital de forma operacional, sem nenhum tipo de adaptação ou ressignificação e, muito frequentemente, sem compreender mais profundamente a cultura do ambiente web de forma mais abrangente. Faz-se necessário diferenciar ao menos preliminarmente, o contexto com o qual estamos lidando: o ambiente web é necessariamente digital, todavia, o ambiente digital nem sempre está inserido na web.

A mediação da informação e sua importância tem sido muito discutida na Ciência da Informação, mas nos interessa principalmente os processos de desintermediação e focos de subversão e resistência dentro dessas mesmas Redes. A criação deste espaço é fundamental para o desenvolvimento de uma Smart Curation, que deverá ser um híbrido entre decisões humanas e algorítmicas. E a cultura de convergência, seus desenvolvimentos, seus desafios e até mesmo sua capilaridade, nos leva a isso de formas imprevisíveis.

A preocupação que sempre existiu para a Biblioteconomia e a Ciência da Informação de "disseminar a informação" se torna quase que irrelevante em ambiente web, uma vez que há uma quantidade tão abundante de informação que não há mais exatamente o que ser disseminado - contudo, há o que ser pesquisado e, principalmente, há o que ser revelado. O próprio consumismo resvala na qualidade do 
que é consumido e essa qualidade, de acordo com Martel, necessariamente deve perpassar por algum tipo de filtro, que seria a curadoria.

\subsection{Cultura e Curadoria}

A Smart Curation abordada por Martel (2015) trata exclusivamente do ambiente web enquanto contexto, com foco em redes e mídias sociais, uma vez que é nela que se encontra o processo de produção e gestão de conteúdo que, dependendo do usuário ou instituição em questão e de seus objetivos, pode se tratar de uma curadoria.

Em entrevista com Hernan Botbol, o mesmo afirma que "o novo modelo econômico da cultura não virá das vendas digitais que acaso tomem o lugar das vendas analógicas. Virá das assinaturas ilimitadas” (apud MARTEL, 2015, p. 256), falando propriamente de conteúdo que pode ser veiculado via streaming. Conta-se e muito num primeiro momento, com a total convergência de conteúdos materiais para o mundo digital e imaterial, como se ocorresse uma substituição e não uma transformação. Martel foca muito nesta questão, partindo dos elementos que traduzem essa nova versão de produtos que, na atualidade, são cada vez mais entendidos como serviços:

A experiência do Taringa traz à luz vários elementos decisivos da cultura da era digital: a assinatura, a recomendação, o algoritmo, a conversa, as novas formas de copyright e a qualidade do content (como costumam ser chamados os "conteúdos"). Mais claramente ainda, esse site mostra que a cultura, que era um "produto cultural", está se transformando em "serviço" (MARTEL, 2015, p. 257).

É preciso lembrar que estas grandes empresas de tecnologia estão inseridas em um contexto mercadológico dominante e com agendas próprias, como é possível verificar no recente caso da Amazon, da Biblioteca Nacional no Brasil e da Prefeitura de São Paulo utilizando a Livraria Cultura como exemplo e referência de gestão de biblioteca pública. Contexto, nesse caso, é importante e mais importante ainda é questionar como e para qual público exatamente estas estratégias querem oferecer 
um diálogo e qual seria a própria natureza deste diálogo. A questão da "conversa" através de uma experiência mais interativa promovendo a aproximação entre instituições, empresas e o público pode ser compreendida no caso da Pinacoteca com a IBM na criação do Watson.

Tratando-se de estratégias para desenvolvimento de conteúdo digital, o capítulo de Smart Curation cita vários exemplos, incluindo museus de arte como o Metropolitan Museum of Art (MET-NYC), com a criação de sua própria timeline e publicação de catálogos online, preocupação em ser referência. O MOMA, mais reservado, com apresentações interativas dos quadros e recursos sobre arte apenas para associados. E o Artsy.net, que é considerado o "Netflix de obras de arte" com recomendações automatizadas e o seu Art Genome Project, processo de reconhecimento das obras que tem empresas como o Google e o Twitter como investidores.

Todas as instituições culturais americanas têm como prioridade estabelecer
uma "conversa" com seu público. Para isso, paradoxalmente, são ajudadas
pela virada digital. Com seus sites, seus aplicativos e sua presença nas redes
sociais, elas se aproximam de seus membros, dirigindo-se a professores e
estudantes. E também se inserem mais em sua "comunidade", mantendo-se
conectadas aos educadores sociais e a todo o chamado setor das CDC
(Community Development Corporations) que trabalham nas regiões carentes.
Por surpreendente que possa parecer, a Internet não é para elas uma
ferramenta de comunicação global, mas, pelo contrário, um meio de se
localizar novamente, participando da conversa local (MARTEL, 2015, p. 262).

É possível traçar um paralelo com a teoria de Marshall McLuhan (1969) que compreende que a humanidade como um todo passou por um processo de tribalização, destribalização e retribalização. Com a Internet e a cultura digital, não é diferente e estes processos (de territorialidade, global e local) se dão sucessivamente. A questão da territorialidade ora se faz pertinente, ora não - depende diretamente do objetivo da estratégia digital a ser construída. O texto de Martel não se preocupa em buscar muita linearidade, no entanto, são abordados exemplos da Índia com a Flipkart e da Rússia com a Ozon.ru, ambas empresas de varejo que competem com a Amazon, que não conseguiu se adaptar aos costumes das pessoas nesses respectivos países. 
E se as variantes locais logo chamam a atenção de um olhar estrangeiro, servem simplesmente para atestar que a localização é sempre indispensável, seja na escolha dos produtos oferecidos ou dos métodos de entrega. Mais ainda que o resto da internet, o setor do comércio on-line permanece extremamente territorializado - e assim continuará (MARTEL, 2015, p. 286).

Os grandes investidores - os mecenas dos dias atuais - muitas vezes se tratando de empresas multinacionais, têm seus headquarters alocados no Vale do Silício, em grandes empresas de tecnologia. A sigla GAFA utilizada para designar as empresas digitais americanas Google, Apple, Facebook e Amazon que a princípio são concorrentes, porém sempre se unem quando necessário para defenderem seus interesses, entre eles, a cultura imaterial que existe e é criada na/e para a Internet. A Amazon Web Services pode ser considerada um exemplo, uma vez que é tão gigante e possui servidores tão robustos que ajuda concorrentes como a Netflix e o Dropbox com suas necessidades de espaço.

Com o tempo, portanto, os GAFA, considerando-se seu poder de ataque, sua
fenomenal capacidade de estocagem e o número de usuários, podem vir a
ser os únicos verdadeiramente capazes de oferecer um serviço global de
assinatura ilimitada para toda a cultura - música, cinema, vídeo games e
livros. Uma hipótese para qual devemos estar preparados (MARTEL, 2015,
p. 283).

Não só devemos estar preparados como também é uma hipótese um tanto quanto preocupante existir tanto poder e informação sob o domínio de apenas quatro companhias no mundo inteiro. Ainda sobre desintermediação, Martel trata sobre o desaparecimento de jornalistas e críticos especializados, baseando-se no Gawker, site de fofoca de celebridades.

Abordando de veículos midiáticos, é possível começar a tratar de curadoria de conteúdo através do modelo de curadoria de notícias, que geralmente costuma ser híbrido, dividindo-se em curadoria de conteúdo de terceiros, de conteúdos originais e curadoria de algoritmos (sendo este último muito utilizado também pelo site Buzzfeed). A questão da curadoria de algoritmos é um tanto quanto problemática, mas suscita estudos mais aprofundados sobre o que seriam tendências de assuntos e temas e de que modo são abordados. Em meio a isso, é criado um vocabulário recheado de estrangeirismos que tratam mais ou menos das mesmas coisas: cool hunters, trend- 
setters, taste-makers e media-gossip, todos com especialidade no que é buzz, coole hip, enfim, tendências.

Algumas técnicas de Search Engine Optimization (SEO) são utilizadas para impulsionar posts - que contam com o trabalho de indexação de títulos, que ainda é feito por humanos - e muitas chamadas são deliberadamente caça-cliques, para que gerem conversão em vendas, propagandas, etc. Entre os problemas trazidos pela curadoria algorítmica, podemos entender que muitas vezes é privilegiado o que é mais viral, não necessariamente o que é verdade, o que traz à tona questões de legitimidade, credibilidade e validação.

Além do viral, tem a questão de publicações patrocinadas que, muitas vezes, por serem pagos, atingem mais pessoas do que outras publicações que possuem relevância e qualidade. Como isso tudo funciona numa época em que é a pós verdade que conta?

\begin{abstract}
A internet por sua própria natureza induz o fim das hierarquias, a desintermediação, a descentralização, o desaparecimento das legitimidades elitistas - desdobramentos que inevitavelmente afetam a crítica. Entramos numa cultura que se caracteriza por "conversas" e não mais por argumentos de autoridade, uma cultura na qual a recomendação tornou-se central, mas ao mesmo tempo fez multiplicar aqueles que recomendam, infinitamente. [...] passando a integrar novos critérios como a e-reputação, a popularidade, a "comunidade" a qual se pertence, ou a que alguém reúne ao seu redor. [...] É a grande disrupção das hierarquias (MARTEL, 2015, p. 297-298).
\end{abstract}

Alexandra Molotkow apud Martel (2015) afirma que "o populismo é o novo modelo do cool; os elitistas são os novos ultrapassados". Na verdade, o tom de voz e a dinâmica do conteúdo online não podem ser confundidos e muito menos substituídos por um conteúdo mais denso, promovendo assim o empobrecimento do pensamento e da linguagem (com curtidas, blurbs e tweets, para citar alguns exemplos). O conteúdo ainda é mais importante do que a propaganda, no entanto, no ambiente em rede em que são utilizados algoritmos de recomendação, entende-se que eles não são infalíveis, pois podem existir distorções de recomendação. A questão que se coloca cada vez mais é: até que ponto se trata de recomendações genuínas ou propaganda? 
Em meio a outras questões, tais como findability, serendipidade e desconfiança de algoritmos arbitrários pautados pela audiência, meios de comunicação tradicionais como o New Yorker não perdem suas características e essência, mantendo sua pertinência, ao mesmo tempo que se adapta em ambiente web, com textos densos, longos e críticos. E estes textos ainda têm seu público.

Martel (2015, p. 304) compreende que "as máquinas [...] encontram dificuldades para prever comportamentos e gostos, escolher ou, mais ainda, julgar emoções e sensibilidades", não sendo capazes ainda de inovar e se aventurar, imaginar, ou fazer associações de ideias, estados de espírito, o que leva a recomendações cada vez mais acanhadas. Os resultados tendem a ser quantitativos, mas não qualitativos, impessoais, o que causa ruído, critérios muito lógicos, criando uma certa eugenia de categorizações, a criação de uma bolha conceitual, desestimulando a diversidade - bem diferente dos humanos.

\begin{abstract}
As redes sociais vendem os dados de recomendação dos milhões de mensagens trocadas diariamente pelos usuários. Os anunciantes, assim como os diretores das indústrias criativas, das mídias e das agências de assessoria e avaliação de audiência, estão em busca de dados precisos, em tempo real, sobre os centros de interesse dos consumidores, seus hábitos, os movimentos da opinião pública, muito além dos meros trending topics tornados públicos. [...] Cabe pensar, creio eu, que as redes sociais vão desempenhar futuramente um papel decisivo na prescrição e na disseminação das informações relativas à cultura, mas é preciso guardar na lembrança todas estas distorções da recomendação (MARTEL, 2015, p. 309).
\end{abstract}

Algoritmos levarão mais alguns anos para aprenderem nuances, sensibilidade e questões de gosto como humanos. Nesse ínterim, ao que tudo indica, o que era a tela da televisão nos anos 80 vai rapidamente se transformando numa tela interativa do computador, com teclados. Não apenas as questões de recomendação algorítmica estão vindo à tona, como também as questões do próprio comportamento humano, que em alguns casos se tornam verdadeiras neuroses pós-modernas, tais como a FOMO (Fear of Missing Out, ou "medo de perder algum evento", em tradução livre), em que a pessoa em questão possui medo de se sentir desinformada ou "por fora" de determinado acontecimento e, também, as questões como a síndrome da metaexperiência, onde a pessoa busca pelo máximo de recomendações e filtros possíveis 
para ter uma pré-experiência e não "perder tempo" com uma experiência ruim, evitando frustrações com a fruição propriamente dita a todo e qualquer custo.

\begin{abstract}
Qualquer um pode ver também que essa mutação e essa aceleração das mídias tem efeitos múltiplos e contraditórios: os livros transformam-se em breves ensaios; os ensaios, em tribunas livres; as tribunas, em posts de blogs; e os blogs, em tuítes. Na imagem e no som, o rádio transforma-se em podcast, e o podcast, em streaming; a televisão evolui para a tela conectada, a SVOD ou Netflix; e a MTV, por sua vez, é hoje em dia o YouTube! (MARTEL, 2015, p. 299-300).
\end{abstract}

Para Merlo Veja (2014) cada uma dessas mídias, criadas pelas Community Development Corporations, há em contrapartida sempre um (ou ainda, vários) community managers, que atua como filtro humano facilitador e mediador. Um exemplo de mediação via internet são os podcasts abordados por Martel (2015, p. 279), que os entende como "uma tecnologia de transição: seu defeito é ser frio, não ser ao vivo. Ele está condenado pela abundância e pelo fato de uma transmissão ser facilmente perecível ou menos pertinente". No entanto, essa abundância garante a diversidade e os podcasts funcionam em torno de um tema comum, principalmente no desenvolvimento de comunidades com interesse nesse mesmo tema, se tornando uma fonte de informação com singularidade e autenticidade.

O autor entende a Smart Curation como um processo que necessariamente passaria por três etapas:

1. Uma dupla filtragem (recomendação via algoritmos e também do tratamento humano por curadores);

2. Uma terceira mediação através de triagem, por um terceiro curador;

3. Um espaço que permita uma "conversa": trata-se de um diálogo que possibilite trocas de informações, idas e vindas, pluralidade de gostos, elaborando-se diferentes "esferas de julgamento". De acordo com Martel, booktubers e Mini-Oprahs já são uma realidade e providenciam este espaço e conversa.

Finalmente, a Smart Curation para Martel seria um hibridismo entre a seleção algorítmica (smart) e humana (curation) de conteúdos, para lidar com o calcanhar de Aquiles da Internet: a abundância. Isso envolverá esferas de gosto, pluralidade de 
recomendações. Ao invés de entender a curadoria versus a mera agregação de conteúdo, a intenção será a de realizar uma combinação das duas, uma vez que "as internets são descentralizadas, descentradas, plurais, caracterizadas pela desintermediação" (MARTEL, 2015, p. 310).

Num sentido similar está a proposta teorizada por García Gutiérrez (2006), quando trata da abertura de um espaço para o que ele chama de estudo epistemográfico possa ser viável.

A expansão do digital e da tecnocultura obriga, sem dúvida, a um exercício de pluralismo ético, que consiste em criar ferramentas que não apenas auxiliem na organização dos "conhecimentos dominantes", mas, especialmente, que promovam a resistência dos conhecimentos considerados subalternos. Esses conhecimentos, culturas e memórias estão ameaçados por projetos globalizantes de substituição e, consequentemente, não Ihes resta outra saída senão apropriarem-se do digital como única possibilidade de autodesenvolvimento (devolver a diversidade com as tecnologias unificantes, dirá James Clifford). Incorporar nas redes digitais os conhecimentos excluídos dos fluxos em que transitam os conhecimentos dominantes: essa seria, resumindo, uma função tecnopolítica da epistemografia interativa (GARCÍA GUTIÉRREZ, 2006, p. 105).

O autor acredita na promoção do dissenso para o aumento do diálogo e, consequentemente, do conhecimento. Este tipo de apropriação do conhecimento, realizado pela via da cultura, pode ser viabilizado através da mediação dos saberes, da ampliação dos espaços para promoção dessa nova sociedade global - seja ela digital ou até mesmo física. Martel, em consonância com este discurso, acredita que o verdadeiro risco, portanto, não é tanto o mainstream, mas a compartimentalização dos assuntos em nichos herméticos, sem interseções nem interações.

Embora exista tudo o que foi abordado neste artigo, o bottom line de Martel ao final do capítulo é o de que não existe fórmula milagrosa para se ter sucesso na Internet. Mesmo que algoritmos sejam considerados poderosos, ainda dependem de uma programação humana e "a definição de regras para um algoritmo jamais é imparcial e é enviesada pela visão de mundo de quem o cria". Martel (2015, p. 321) ressalta, ainda, que os algoritmos podem "levar ao mainstream; podem estar vinculados a contratos publicitários; podem, em sentido inverso, conduzir a nichos, à world music, ao cinema mundial, à literatura de vanguarda ou à arte mais 
contemporânea. Depende dos critérios e parâmetros estabelecidos”. Entende-se, por fim, que a máquina não será o futuro da crítica.

Em relação à curadoria, o tema da cultura digital auxilia no levantamento de algumas questões referentes a esta prática: é possível identificar a existência de uma "agenda" por trás da idealização de alguns tipos de curadoria, dependendo de seu contexto? A questão da imparcialidade - que abrange também a comunicação como um todo - do recorte enquanto crítica, se faz presente em que medida neste processo? De que modo o recorte ou a crítica podem acabar por comprometer uma abordagem mais objetiva e informacional dos produtos de curadoria na Ciência da Informação? 


\section{CURADORIA: ASPECTOS E PREMISSAS TEÓRICO-CONCEITUAIS}

Buckland (2007), em seu artigo Naming in the library: Marks, meaning and machines, entende que o estudo da terminologia, seu uso e os processos, lidam diretamente com desenvolvimento contínuo. Para o autor, profissionais e cientistas da informação precisam ter uma postura como a do Deus Jano: é preciso saber lidar com os legados históricos, com o passado e com a memória dos termos, ao mesmo passo que é necessário acompanhar as mudanças e desenvolvimentos que ocorrem no mundo, nas tecnologias e no tempo presente.

Pela etimologia, o termo curadoria a partir de sua origem no latim ${ }^{6}$ curare, significa cuidar, zelar, tratar. No entanto, o termo também pode ser compreendido a partir de sua origem no tupi-guarani ${ }^{7}$, onde curare significa um "veneno de ação paralisante, com efeito letárgico e de catarse, usado para caça". Além dessa curiosa diferenciação etimológica é possível compreender que o termo curadoria é polissêmico, uma vez que possui diferentes significados para cada área do conhecimento, de acordo com cada contexto em que se apresenta.

Machado e Vianna (2016) em estudo sobre o tema, concluíram a partir da clusterização do conceito de "Cultura Digital", especificamente, que uma característica transversal a todos os conceitos - quando de sua clusterização - é a do ciclo de vida da informação, com ênfase no processo de gestão e controle. O estudo, realizado em bases bibliográficas internacionais em Cl (EBSCO; Emerald; ProQuest; Scopus; Science Direct e Wiley Online Library) recuperou, entre os anos de 2000 a 2015, um portfólio bibliográfico composto por 13 artigos científicos que tratam sobre o tema.

\footnotetext{
Além disso, o caráter interdisciplinar da Curadoria Digital permite a agregação de conhecimentos de outras áreas, pois se preocupa não só com a acessibilidade da informação como com a sua preservação para uso futuro. Assim, percebe-se uma relação entre o tratamento da informação e a democratização da informação, pelas quais se pode ter não só a usabilidade dos dados digitais, mas também recuperação, transmissão e utilização destes, visando não só esse tratamento como suprindo as necessidades de informação de todo tipo de usuários (MACHADO; VIANNA, 2016).
} 
De acordo com a literatura dos artigos de periódicos científicos internacionais recuperados por Machado e Vianna (2016, p. 15), "as características das ações vinculadas à curadoria digital, percebe-se que muitas, senão todas, contemplam o desenvolvimento teórico e prático em Ciência da Informação".

É importante salientar que alguns artigos do portfólio bibliográfico tratavam mais sobre questões de aplicabilidade da curadoria (uso prático com alguma ferramenta ou em lugares específicos), sobre algumas questões históricas (mostrar de onde se originou a curadoria) (MACHADO, VIANNA, 2016, p. 11).

O possível diferencial da curadoria se trata, não apenas de uma primeira seleção de material, mas principalmente de sua customização, ou seja, uma seleção do que já seria uma seleção - implicando em outros fatores para além da recuperação e preservação da informação. Corrêa e Bertocchi (2012) descrevem que este processo de customização teria, em tese, o efeito de fazer com que as pessoas percam menos tempo, em uma sociedade em que a produção e a publicação de informação é realizada de forma vertiginosa, e observam que:

\footnotetext{
Sob o ponto de vista do campo da Comunicação, apreciamos uma imagem de abundância informativa, alavancada pelas redes digitais, e, ao mesmo tempo, o surgimento, na própria rede, de propostas curatoriais organizadoras. [...] Como pano de fundo, tem-se os diversos aspectos de construção de conhecimento individual, coletivo e social que no contexto atual requerem uma intervenção mediadora (que mais adiante veremos como re-mediadora) (CORRÊA, BERTOCCHI, 2012, p. 5-6).
}

As autoras compreendem que o processo curatorial se vale da correlação de conteúdos, como se ele fizesse parte de um processo de mediação cruzada ao qual chamam de "re-mediação". Ao mesmo tempo em que existe a possibilidade do mundo online, existem instituições que trabalham a curadoria de forma digital de forma mais objetiva, como a Digital Curation Centre (DCC) na Inglaterra "oferecendo serviços e produtos para a comunidade que trabalha com a curadoria de materiais digitais, oferecendo apoio à comunidade para trabalhar em rede e facilitar formas de acrescentar valor aos conteúdos digitais", destaca Márdero Arellano (2008, p. 188). 
Uma vez em que vivemos em uma época de estruturas híbridas, em que tentamos conciliar os objetos criados a partir do mundo físico com as possibilidades do mundo digital (e vice-versa), conceitos como o de Curadoria - que por muitas vezes possuem um caráter polissêmico - podem determinar produtos e pesquisas distintos, de acordo com a disciplina de conhecimento em que esteja inserida. A própria popularização do termo Curadoria na $\mathrm{Cl}$ deve em muito às novas tecnologias de informação e comunicação (TICs) e, por isso, se faz necessário diferenciar as nuances de seus possíveis qualificadores.

Sierba, Borda e Miranda (2016, p. 3) em seu trabalho sobre sobre Curadoria Digital como termo interdisciplinar, buscam elucidar especificamente a Curadoria Digital a partir de uma perspectiva abrangente. Ainda, as autoras compreendem que a polissemia do termo se deve ao fato de se tratar de "uma prática naturalmente interdisciplinar, combinando questões tecnológicas, comunicacionais, gerenciais, cognitivas, de geração de conhecimento e informacionais".

Especificamente em relação contexto de Curadoria Digital, Sierba Borda e Miranda (2016) em seu estudo observaram três tipologias de curadorias, cada uma com uma especialização diferente: curadoria de conteúdo, curadoria digital o e curadoria de dados. Estas tipologias ressoam com os conceitos encontrados por Machado e Vianna (2016) sobre o mesmo tema, que categorizam as características comuns acerca do conceito de Curadoria Digital em: uso e reuso da informação digital; manutenção, planejamento e arquivamento digital; e gestão de dados.

A Curadoria de Conteúdo se preocuparia com as questões de uso e reuso da informação digital, ao mesmo tempo em que agrega valor através de filtragem de dados, possibilitando sua conversão em informação. Siebra, Borda e Miranda (2016, p. 9) afirmam que o papel fundamental que emerge desse tipo de curadoria é o da mediação, no qual ressaltam:

Também, por seu perfil, a curadoria de conteúdo inclina-se para necessidades imediatistas de informação sem muita preocupação com a gestão e preservação dos dados a longo prazo. De fato, ao pesquisar, selecionar, agregar valor, organizar e compartilhar conteúdo, a curadoria contribui para aumentar a estruturação e difusão de informações e intensificar o fluxo de conteúdos necessários à produção de conhecimento. Logo, podese dizer que a curadoria de conteúdos objetiva alcançar audiências específicas, o que a aproxima das atividades de marketing, jornalismo, educação, comércio e mídias sociais (SIEBRA; BORDA; MIRANDA, 2016, p. 9). 
A Curadoria Digital, segundo as próprias autoras, se aproximaria de um conceito mais voltado para a preservação, podendo ser considerado a evolução dos termos preservação digital e arquivamento digital (SIEBRA; BORDA; MIRANDA 2016, p. 9). A curadoria digital, segundo o Digital Curation Center (DCC, 2004-2016) visa a gestão ativa, agregação de valor à informação digital e a preservação de recursos digitais, tanto para uso atual quanto futuro, durante todo o ciclo de vida do dado digital.

Este ciclo de vida é muito utilizado, visto que assegura todos os passos necessários para uma curadoria e preservação efetivos. Uma vez que os conhecimentos críticos estejam identificados, planejados e implementados na sequência correta, é possível garantir a manutenção, autenticidade, confiabilidade, integridade e usabilidade do objeto digital.

Já a Curadoria de Dados está relacionada a gestão de dados científicos, especificamente, voltando-se para e-Science. De acordo com Santos (2014), ela engloba atividades de gestão requeridas para "manter e gerir dados de pesquisa a longo prazo, de modo que eles estejam disponíveis para o reuso, favorecendo a colaboração entre pesquisadores, o avanço da ciência e a preservação do conhecimento científico". Há a preocupação com a memória digital institucional e a promoção do compartilhamento para acesso e reuso dos dados de pesquisa.

Para Buckland (1991) é interessante notar a abrangência da Curadoria Digital do ponto de vista de sua capacidade de contemplar: a) informação como coisa; b) informação como conhecimento, e; c) informação como processo. Deste modo, compreendem-se alguns aspectos onde a Curadoria se encontra, a saber: curadoria de conteúdo, curadoria de preservação e curadoria de dados. Sugere-se, para trabalhos de pesquisa futuros, a ampliação da pesquisa sobre o termo de "Curadoria Digital", bem como de todo o processo a outras bases disponibilizadas pela CAPES.

No entanto, uma indicação hierárquica e específica (tratando aqui do Digital), pode ser limitadora. Em adequação à pesquisa científica seria apropriado verificar com base na literatura em quais locais - ou ainda, em quais Jogos de Linguagem da $\mathrm{Cl}$ a Curadoria está e quais significados ela assume nestes lugares. Para cada jogo, os propósitos e o funcionamento das práticas de curadoria podem oscilar. Esta verificação e análise nos permite tratar sobre o tema de forma mais abrangente, escapando da obrigatoriedade da classificação de Curadoria como subdisciplina. 
É justamente o desenvolvimento desta pesquisa de revisão que irá sugerir aproximações, sem assumir a priori um ponto de partida. No momento inicial, cabe uma apresentação da Curadoria em perspectiva histórica e interdisciplinar, no contexto dos periódicos em $\mathrm{Cl}$ brasileiros. Isto fornecerá subsídios e tessituras para a análise de limitações e alcances dos conceitos e de suas práticas, na $\mathrm{Cl}$ e em relação a Cultura Digital. Ao contribuir com mais reflexões acerca do conceito de Curadoria dentro do campo de $\mathrm{Cl}$, será possível indicar com mais precisão este movimento da Curadoria, nestas áreas e nas disciplinas. 


\section{METODOLOGIA DE PESQUISA}

Estudos de Terminologia e de Socioterminologia (FAULSTICH, 2006), bem como os produtos advindos das Linguagens Documentárias, foram criados desde seu princípio levando em conta a linguagem utilizada pelo meio social onde estavam inseridos, sendo este um de seus principais objetivos quando de sua criação e desenvolvimento. A Análise de Conteúdo, de acordo com Bardin (2010), realiza-se principalmente por classificação-indexação, com técnicas temáticas e frequenciais, em que os documentos são avaliados de acordo com o seu contexto.

De modo um pouco mais abrangente, pode-se afirmar que neste estudo serão utilizadas técnicas de pesquisa documental, visto que, para Gil (2002, p. 51) as mesmas se valem de "materiais que não receberam ainda um tratamento analítico, ou que ainda podem ser reelaborados de acordo com os objetos da pesquisa", uma vez que na pesquisa documental, as fontes são muito diversificadas e dispersas. A dissertação basicamente será composta de levantamento bibliográfico e referencial de artigos da área.

Em resumo, como já posto, a presente pesquisa realiza um breve estudo terminológico acerca do termo "Curadoria" nos periódicos da área de Ciência da Informação no Brasil e seus temas relacionados. Tangencialmente, a pesquisa também trata da importância da comunicação científica e do próprio alcance do periódico científico, que tem por objetivo permitir que estudos tenham visibilidade nacional e internacionalmente.

Em relação ao método, Bardin (2010) descreve a organização da análise em três fases, que adaptadas são compostas por:

a) Pré-análise: estabelecimento de critérios e definição do corpus da pesquisa. Esta etapa da pesquisa será desenvolvida no Capítulo 6 de Metodologia;

b) Exploração do Material: aplicação sistemática das decisões tomadas na pré-análise, codificação, decomposição e sistematização do corpus; esta etapa será desenvolvida no Capítulo 7 , ao longo da análise quantitativa (7.1); 
c) Tratamento dos resultados, inferência e interpretação: a partir dos resultados encontrados nos artigos recuperados, os termos mais frequentes serão elevados ao status de categoria e analisados individualmente. Esta etapa será desenvolvida no Capítulo 7 , ao longo da análise qualitativa (7.2).

\subsection{Critérios de seleção de periódicos}

A base bibliográfica selecionada para recuperação dos periódicos é o sistema Qualis da CAPES através da Plataforma Sucupira ${ }^{8}$, que organiza um ranking de periódicos de acordo com comissões de avaliação, divididas por áreas do conhecimento. A base em questão foi selecionada, pois trata-se de uma referência de qualidade nacional - não somente por impactar diretamente na produtividade via Lattes - mas por existirem critérios para indexação de periódicos - de acordo com diferentes estratos - sendo realizadas reavaliações tri ou quadri-anuais nacionalmente.

O levantamento de periódicos foi realizado em dois momentos: primeiramente em setembro de 2017 e depois novamente revisado e definido em março de 2018. $\mathrm{Na}$ página Qualis Periódicos ${ }^{9}$, no campo "Evento de Classificação" selecionou-se o valor "Classificação de Periódicos Quadriênio 2013-2016" e no campo "Área de Avaliação" foi selecionado "Comunicação e Informação".

Foram então selecionados 15 periódicos científicos nacionais em $\mathrm{Cl}$, todos pertencentes aos estratos $\mathrm{A} 1, \mathrm{~A} 2$ e $\mathrm{B} 1$.

Entre as dificuldades técnicas encontradas em relação a plataforma Sucupira, é possível relatar que:

- Não existe divisão clara das Áreas de Conhecimento na plataforma dos periódicos em Comunicação, Ciência da Informação e Sociologia, Filosofia, Antropologia, Audiovisual;

8 Acesso em: https://sucupira.capes.gov.br/sucupira/public/index.xhtml 9 Acesso em:

https://sucupira.capes.gov.br/sucupira/public/consultas/coleta/veiculoPublicacaoQualis/listaConsultaGeralPeriodic os.jsf 
- Não existem hiperlinks redirecionando o usuário para os periódicos em específico, a busca deve ser feita manualmente via Google e/ou através dos respectivos ISBN;

- Não existe separação entre periódicos bilíngues, nacionais ou internacionais (mesmo que se tratando de países da América Latina). No caso, o pesquisador-usuário que realiza a busca na base já deve estar familiarizado com os periódicos.

Em relação aos periódicos nacionais e suas plataformas, foi encontrada dificuldade na manutenção da tecnologia de ferramenta de busca (search engine). Isso pode ser percebido através da comparação de resultados entre busca automatizada e busca manual, onde muitas vezes as ferramentas de busca não trouxeram resultados satisfatórios, dificultando a pesquisa. Neste sentido, três periódicos apresentaram falhas em seus mecanismos de busca, não recuperando nenhum artigo. Nestes periódicos em específico foi realizada a busca manual e os artigos que efetivamente condiziam com o tema pesquisado, foram inclusos posteriormente na pesquisa.

\subsection{Mapeamento do Corpus da Pesquisa}

$\mathrm{Na}$ ferramenta de busca de cada um dos periódicos selecionados foi pesquisado apenas o termo "Curadoria". O escopo da busca foi definido como "Todos" o que inclui na busca: título, resumo, palavras-chave e texto completo. A seguir, o gráfico de árvore auxilia a visualizar de que modos o termo foi encontrado no material analisado. 
Quadro 2 - Frequência do termo 'Curadoria' nos metadados analisados.

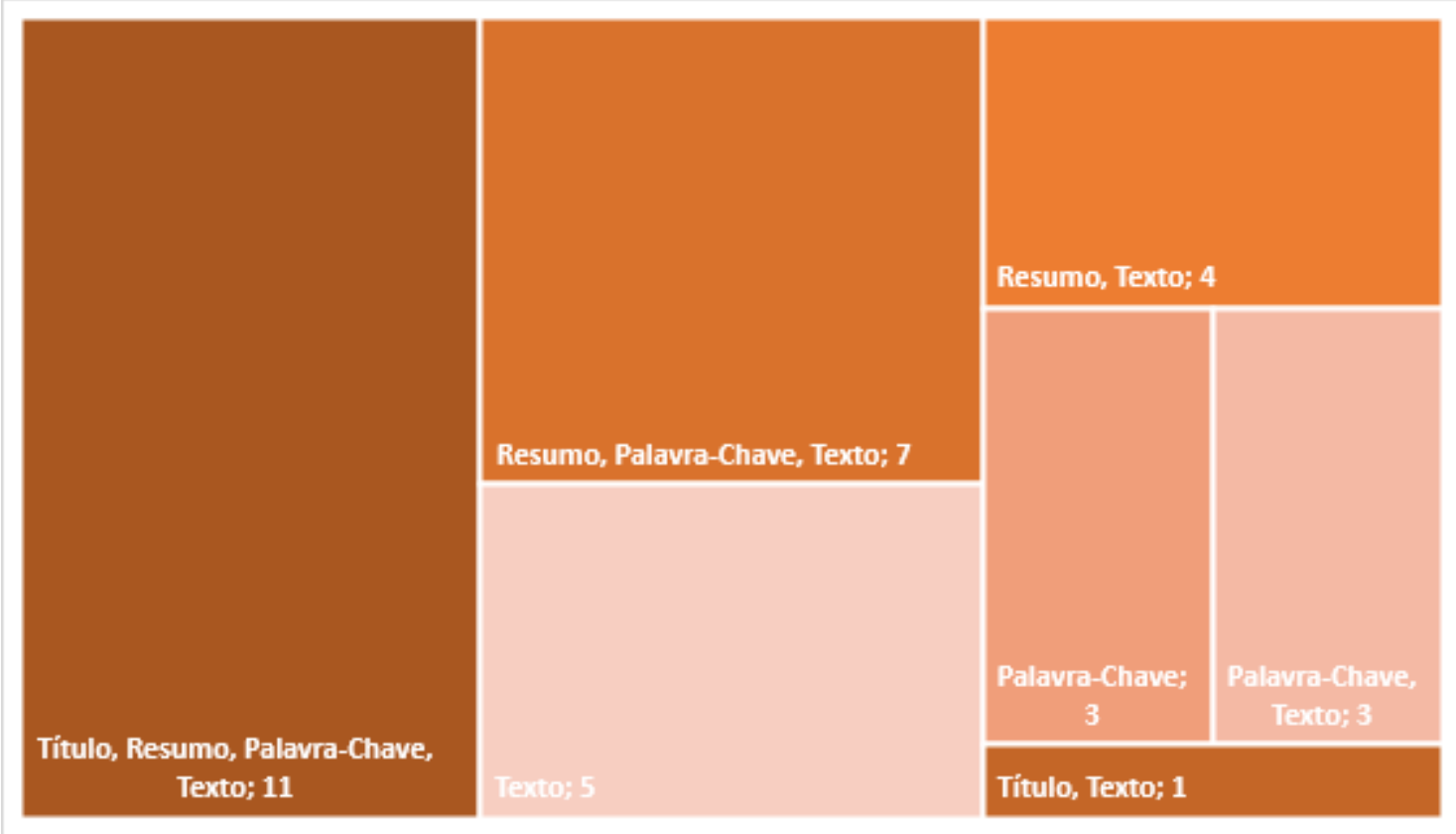

Os artigos recuperados foram analisados individualmente, visto que o termo "Curadoria" por muitas vezes apareceu no texto completo apenas como menção, sendo que, no entanto, o artigo em questão tinha seu foco principal em outro tema de discussão. A decisão foi de incluir na pesquisa apenas artigos completos que efetivamente tratassem do tema de Curadoria - comunicações, resumos, revisões, traduções, cartas aos editores, editoriais, relatos e resenhas foram desconsiderados.

A definição dos periódicos a serem trabalhados e o mapeamento dos artigos completos e definição de quais artigos seriam inclusos na análise, foi realizado no primeiro semestre de 2018. De um total de 15 periódicos selecionados, foram recuperados 33 artigos, considerados suficientes para delinear alguns resultados. Como será mostrado posteriormente no Capítulo 7.1 de Análise Quantitativa, é possível compreender que a literatura sobre o tema na área de $\mathrm{Cl}$ ainda é incipiente, o que possibilita uma maior exploração em longo prazo. 


\subsection{Análise de Conteúdo}

Além de pesquisa quantitativa acerca da produção recuperada, os contextos em que o termo foi utilizado foram analisados sistematicamente, utilizando-se da técnica de Análise de Conteúdo, de Laurence Bardin (2010). A análise e compreensão da produção identificada permitiu entender o conceito do termo de forma um pouco mais ampla, tendo utilizado esse material como primeiro corpus de pesquisa.

A documentação selecionada teve seu conteúdo codificado para uma possível representação e interpretação. De acordo com Bardin (2010, p. 127), o pesquisador "tendo à sua disposição resultados significativos e fiéis, pode então propor inferências e adiantar interpretações a propósito dos objetivos previstos - ou que digam respeito a outras descobertas inesperadas".

$\mathrm{Na}$ primeira etapa, a pesquisa teve caráter exploratório e descritivo, com abordagem quali-quantitativa - no qual foi verificada a frequência e a relação dos termos analisados. A princípio, a exploração do material selecionado se constituiu pela análise dos títulos, palavras-chave e resumo. A análise foi realizada em três etapas que compreendem: a) Levantamento e listagem das palavras-chave; b) Tratamento das palavras-chave; e, c) Sugestão de proposta de categorização para análise. Para uma melhor compreensão do contexto dos documentos analisados, posteriormente foi realizada a leitura dos artigos, a ser aprofundado no capítulo de Resultados e Discussão.

No total, foram levantadas 160 palavras-chave de todos os documentos, sem nenhum tratamento prévio. De todas as palavras-chave levantadas, 46 foram atribuídas pela autora a 11 documentos, já que na documentação original a descrição do assunto se apresentava incompleta. Ao final do tratamento, o índice de termos selecionados para a pesquisa compreendeu 109 termos únicos, sem duplicações e relacionáveis entre si.

Após o tratamento, as palavras-chave adquiriram status de termos que foram analisados em categorias, de acordo com a sua frequência. Por exemplo, a categoria "Curadoria Digital" é frequente - dado que, de 33 artigos, este termo se encontra em 24 artigos - tornando-se relevante para a pesquisa. Ainda assim, embora alguns textos 
mencionem o termo "Curadoria", sua aplicação e tema maior pode ser sobre um tema relacionado tal como Preservação Digital ou Repositórios. A discussão foi feita posteriormente. No entanto, o quadro a seguir auxilia a visualizar a organização das categorias a serem analisadas:

Quadro 3 - Categorias de maior e menor frequência na análise do termo 'Curadoria'.

\begin{tabular}{|l|l|}
\hline Categorias Mais Frequentes & Categorias Menos Frequentes \\
\hline Curadoria Digital (22) & Ciência Aberta (4) \\
\hline Preservação Digital (13) & Dado Aberto (4) \\
\hline Arquivo (6) & Informação e Tecnologia (3) \\
\hline Repositório (5) & Design da Informação (3) \\
\hline Competência (4) & E-Ciência (3) \\
\hline Biblioteca (5) & Acesso Aberto (3) \\
\hline Dado de Pesquisa (5) & Outro Tema (2) \\
\hline Museu (5) & \\
\hline
\end{tabular}

$\mathrm{Na}$ categoria 'Outros Temas' encontram-se tópicos de interesse que apareceram com baixa frequência (2 vezes apenas), mas que ainda deverão ser explorados e compreendidos. Na análise, foram encontrados 43 termos únicos (que apareceram uma única vez).

Quanto ao tratamento das palavras-chave, conclui-se que as regras propostas por Bardin (2010, p. 122) - exaustividade, representatividade, homogeneidade e pertinência - vão ao encontro de alguns elementos incluídos em padronizações internacionais, como da ISO 2788-1984 Documentation - Guidelines for the establishment and development of monolingual thesauri. Embora os requerimentos formais da ISO 2788-1984 se apliquem para a criação de tesauros monolíngues, alguns itens foram adaptados para a realização deste trabalho.

Quando do tratamento de algumas palavras-chave, algumas passaram pelo processo de fatoração morfológica (lexicológica), sendo desmembradas, como por exemplo "Repositório digital de dados de pesquisa" para "Repositório Digital" e "Dado de Pesquisa". Os termos foram padronizados no singular e foram descartados da análise os nomes próprios. A exemplo da regra de representatividade e pertinência de 
Bardin (2010), alguns termos foram agrupados em uma mesma categoria, a exemplo: curadoria digital, curadoria, curadoria de coleções, curadoria de conteúdo e curadoria de dados, são termos que fazem parte da categoria 'Curadoria', pois possuem semelhanças que os assemelham. 


\section{RESULTADOS E DISCUSSÃO}

A seção de Resultados e Discussão está dividida em duas partes. Na primeira seção, da parte de Análise Quantitativa, será apresentado um breve levantamento referente ao corpus da pesquisa, analisando quantitativamente os artigos recuperados em periódicos científicos. Na seção de Análise Qualitativa, é possível observar os temas que emergiram a partir da análise quantitativa, de acordo com a proposta metodológica pré-definida e a análise terminológica será realizada de acordo com cada contexto.

\subsection{Análise Quantitativa}

Até março de 2019, prazo final da coleta e análise de materiais, foi recuperado um total de 33 artigos para análise e revisão. Em um primeiro momento, verificou-se a quantidade de artigos recuperados por periódico, conforme cada estrato. O quadro a seguir representa a quantidade de artigos recuperados, de acordo com cada periódico (que tiveram seus títulos preservados) e seu estrato:

Quadro 4 - Relatório qualitativo da produção recuperada nos periódicos em $\mathrm{Cl}$.

\begin{tabular}{|c|c|c|c|}
\hline Estrato & Periódico em Cl & Artigos Recuperados & Total \\
\hline \multirow{3}{*}{ A1 } & Periódico A1-1 & 2 artigos & \multirow{3}{*}{3 artigos } \\
\hline & Periódico A1-2 & 1 artigo & \\
\hline & Periódico A1-3 & Nenhum & \\
\hline \multirow{2}{*}{ A2 } & Periódico A2-1 & 1 artigo & \multirow{2}{*}{5 artigos } \\
\hline & Periódico A2-2 & 4 artigos & \\
\hline \multirow{10}{*}{ B1 } & Periódico B1-1 & 1 artigo & \multirow{10}{*}{26 artigos } \\
\hline & Periódico B1-2 & 1 artigo & \\
\hline & Periódico B1-3 & 5 artigos & \\
\hline & Periódico B1-4 & 2 artigos & \\
\hline & Periódico B1-5 & 1 artigo & \\
\hline & Periódico B1-6 & 2 artigos & \\
\hline & Periódico B1-7 & 1 artigo & \\
\hline & Periódico B1-8 & 7 artigos & \\
\hline & Periódico B1-9 & 4 artigos & \\
\hline & Periódico B1-10 & 2 artigos & \\
\hline
\end{tabular}

Os periódicos B1-3 e B1-8 especificamente se destacaram na quantidade de publicações, pois publicaram edições especiais sobre os temas de Preservação e 
Curadoria Digital. No Periódico A1-3, onde nenhum artigo foi recuperado, além da busca automática via search também foi realizada uma busca manual e, ainda assim, nenhum artigo sobre o tema foi recuperado. A grande maioria dos periódicos se encontram no estrato $\mathrm{B} 1$, e 11 dos 15 periódicos analisados estão vinculados a instituições de ensino superior - tanto federais, quanto estaduais - que possuem programas de pós-graduação em $\mathrm{Cl}$. Os outros periódicos estão vinculados aos institutos de ciência e tecnologia e federações e associações relacionadas à área de Biblioteconomia. As referências de todos os artigos recuperados através deste levantamento constam no Apêndice A.

Quantitativamente, de acordo com o material recuperado para esta pesquisa, foi possível verificar que o termo "Curadoria" passou a ser utilizado em periódicos científicos de $\mathrm{Cl}$ a partir do ano de 2012, passando por um aumento significativo no ano de 2016 - devido a publicações especiais sobre o tema. Embora tradicionalmente o termo possa ser encontrado em outros contextos, tais como museologia e exposições artísticas, ele passou a ser discutido em diferentes contextos na comunidade científica de $\mathrm{Cl}$ com maior frequência nos últimos 4 anos, conforme demonstrado no gráfico a seguir.

Gráfico 1 - Frequência anual de publicações.

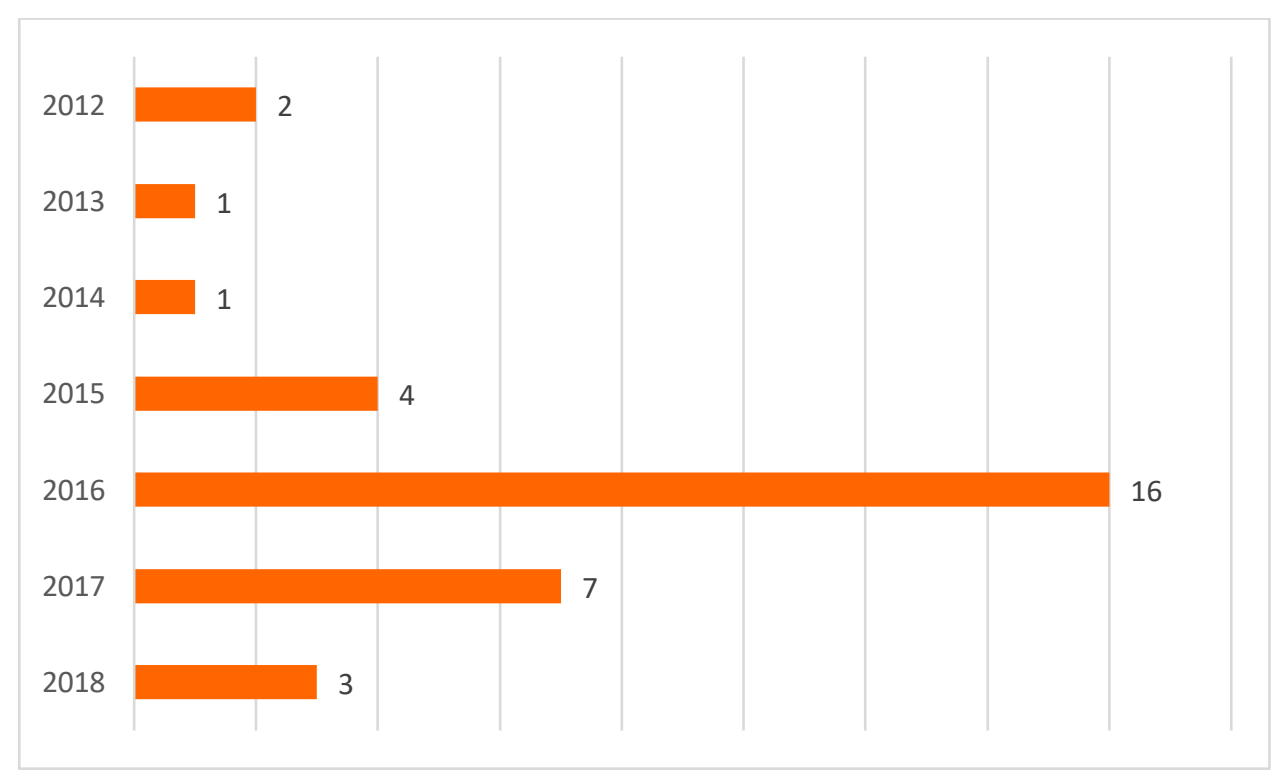

Dos 33 artigos recuperados, apenas três estão em idiomas estrangeiros (sendo dois em espanhol e um em inglês). Um dos periódicos analisados também se 
apresentou como hub (um tipo de agregador) de artigos, indexando em sua base artigos previamente publicados em outros periódicos. Neste caso, foi considerada a recuperação dos artigos a partir de sua proveniência original.

Em relação às temáticas abordadas de acordo com a cronologia apresentada, é possível afirmar que, a partir do ano de 2012 até 2014, o termo "Curadoria" passou a ser vinculado a outros temas relacionados, tais como preservação digital, dados de pesquisa e ciência aberta (ou ainda, e-Science). A partir do ano de 2015, o tema surgiu em outros contextos, onde era vinculado às questões de Cultura, levando em consideração também as questões referentes à informação e tecnologia, metadados, memória na internet, plataformas digitais e web colaborativa.

No ano de 2016 houve um aumento na complexidade dos temas relacionados e uma consolidação da designação de "Curadoria Digital". A Curadoria foi fortemente vinculada a temáticas como acervos e arquivos abertos, bibliotecas (e suas diferentes tipologias, tais como: digitais, acadêmicas e universitárias) e repositórios digitais, sendo novamente reforçada a questão da preservação digital.

Nos anos subsequentes, 2017 e 2018, foi possível verificar vínculos e contextos mais granularizados e especializados, onde a Curadoria poderia se fazer presente, dentro de um macro-contexto na $\mathrm{Cl}$ : arte, cidadania, inclusão social, projetos e redes sociais. Até o último ano pesquisado, houve bastante ênfase na questão da preservação digital e preservação de dados científicos de modo geral, embora os temas tenham também se tornado mais complexos, específicos e refinados ao longo do tempo. Na próxima seção, será possível verificar, de forma mais aprofundada, de que modo o termo "Curadoria" se relaciona com as temáticas apresentadas de forma qualitativa.

\subsection{Análise Qualitativa}

Conforme analisado no Quadro 2, o termo "Curadoria", justamente por ter sido buscado a partir de um escopo mais genérico, teve a maior parte de sua recuperação em texto, do que em título, resumo e palavras-chave. Em um primeiro momento da pesquisa, a intenção era a de realizar a localização do termo curadoria para delinear 
a sua definição de acordo com o material encontrado. No entanto, ao longo da pesquisa, esta questão de identificação foi retrabalhada e a prioridade de investigação foi revista à luz de novas questões.

Diante dos dados já sistematizados, foi possível analisar outras questões referentes ao termo e sua prática, levando em consideração outros temas que estão relacionados com a Curadoria em maior e menor escala. A partir do levantamento e análise do corpus de pesquisa - palavras-chave devidamente tratadas e elevadas à condição de termos, com a extração de seu conceito - foi criada uma categorização não-hierarquizada de termos que se relacionam em maior e menor escala. Analisados individualmente, os conceitos de cada categoria analisada podem fornecer pistas, não sobre o que é a Curadoria, mas sobre onde está e onde se encontra a Curadoria para a Ciência da Informação: tanto suas origens disciplinares quanto interdisciplinares, suas tipologias, métodos e práticas.

Tomando como base a metodologia de Análise de Conteúdo proposta por Bardin (2010), foi analisada a frequência das palavras-chave que descreviam os artigos a fim de verificar a relação da utilização do termo curadoria, como também alguns termos relacionados ao tema principal. Foi criada uma nuvem de tags para melhor visualização dos temas recuperados e que estão relacionados a busca pelo termo "Curadoria":

Figura 1 - Nuvem de tags com os termos mais frequentes e relevantes nas palavras-chave.

Acesso (3) Arquivo (6) Biblioteca (5) Ciência Aberta (4) Competência (5) Curadoria (2) Curadoria de coleções Curadoria de conteúdo Curadoria de dados Curadoria digital (22) Design da Informação (3) E-Ciência (3) Informação e Tecnologia (3) Museu (5) Preservação digital (13) Repositório (5)

O termo que obteve uma recuperação mais expressiva foi o de "Curadoria Digital", juntamente com termos mais específicos como Curadoria de Dados, Curadoria de Coleções e Curadoria de Conteúdo. O segundo termo mais frequente na análise dos artigos foi "Preservação Digital". É interessante notar a frequência com que os lugares onde a curadoria é realizada são sempre mencionados: Arquivo, 
Biblioteca, Museu e Repositório. A Competência Informacional, por parte do desenvolvimento do curador, também teve alta frequência.

Mesmo entre os temas menos frequentes, a questão da Cultura Digital ainda é bastante expressiva: Ciência Aberta, Dados Abertos, Informação e Tecnologia, Design da Informação, e-Ciência e Acesso Aberto. Outros 43 termos únicos foram recuperados, no entanto, não houve repetição. Estes termos serão analisados através de um agrupamento. A partir dos termos recuperados, é possível inferir que o tema de Curadoria, de acordo com o que é entendido e abordado pela $\mathrm{Cl}$, está intimamente atrelado à Cultura Digital. No próximo subcapítulo, é demonstrada a frequência dos termos individualmente.

\subsubsection{Categorias Mais Frequentes}

\section{Curadoria Digital (22)}

A categoria de Curadoria Digital foi a que obteve maior frequência entre os artigos selecionados. No total, foram 17 artigos recuperados pelo termo Curadoria Digital em específico e outros 5 artigos que foram recuperados via termos relacionados, que foram agrupados nesta mesma categoria, a saber: Curadoria, Curadoria de Coleções, Curadoria de Conteúdo e Curadoria de Dados. Através da massa documental analisada, foi possível notar consonância com os estudos realizados por Sierba, Borda e Miranda (2016) e suas tipologias de curadoria.

Os primeiros artigos publicados sobre o tema em periódicos de $\mathrm{Cl}$, sobretudo ao observar os estudos iniciais sobre a Curadoria, são os artigos de Sales e Sayão (2012a; 2012b) que tratavam especificamente de dados de pesquisa e e-Ciência, tendo em vista a sustentabilidade do uso de dados no futuro. A Curadoria Digital para os autores em seus artigos posteriores $(2013,2016)$ estava atrelada à preservação digital e à criação de políticas que assegurassem a proteção aos dados de pesquisa via repositórios digitais. Ainda ressaltam a importância da preservação da memória via curadoria, embora seja no contexto de um recorte científico e tecnológico. Outros estudos se derivaram destes, no entanto, o índice de citação se deve mais ao fato 
destas serem "as primeiras publicações" sobre o tema, e não sobre seu significado em relação a pesquisas posteriores.

Fernandes e Oliveira (2018, p. 259), em sua publicação com foco em arquivo e preservação digital, também mencionaram a Curadoria Digital especificamente pelo viés de Dados de Pesquisa como uma ação estratégica, compreendendo que "tendo em vista que o uso, reuso e compartilhamento dos dados de pesquisa está condicionado à sua preservação, a curadoria digital vem desenvolvendo estratégias, tecnologias e atividades que tornam essa realidade possível". Contudo, foram poucos os artigos recuperados - onde foi plausível de compreender como estudos mais teóricos - em que efetivamente se preocuparam em realizar a diferenciação ou até mesmo verificar as aproximações entre Curadoria Digital e Preservação Digital. Neste sentido, foi possível verificar este tipo de análise em dois artigos recuperados.

Santos (2016) em seu estudo trata diretamente sobre os cruzamentos conceituais e os pontos de interseção e diferenciação entre Curadoria e Preservação Digital, no contexto de dados digitais. Embora sejam profundamente interdependentes, a autora compreende a Preservação Digital como método, processo e modelo, enquanto a Curadoria Digital seria entendida como modelo conceitual para pensar e designar políticas de informação. Gonçalves e Paletta (2016) abordam o papel das bibliotecas na sociedade em rede, realizando um estudo preliminar sobre o papel do bibliotecário como curador no cenário digital. Os autores compreendem a CD como sendo mais ampla que a Preservação Digital:

\footnotetext{
Neste cenário, surge a Curadoria Digital, uma nova área interdisciplinar, que trata do gerenciamento do objeto digital durante todo o seu ciclo de vida. A curadoria digital é hoje vista como um processo mais completo, que trata do planejamento, avaliação e reavaliação das ações em prol da curadoria do objeto digital e que engloba a preservação digital como parte do seu ciclo (GONÇALVES; PALETTA, 2016, p. 48).
}

No sentido de tipologia de pesquisas, foi possível verificar quando da análise dos artigos, que as pesquisas de cunho prático se sobrepõem em frequência às pesquisas teóricas. Dutra e Macedo (2016) realizaram uma proposta de modelo de curadoria em ambiente Big Data. Neste caso em específico, os autores compreendem que a Curadoria e a Preservação Digital tenham certo tipo de equivalência, sem se 
deter muito em definições:

\begin{abstract}
Embora na sua essência, a ideia de Curadoria Digital remeta a um processo de seleção e manutenção de objetos digitais, neste trabalho, para fins didáticos, iremos considerar também como parte integrante da CD os repositórios temáticos resultantes deste processo. A importância desta decisão se deve à necessidade de se representar o processo de seleção semiautomático de objetos digitais em diferentes domínios de conhecimento. Não é objeto deste trabalho, no entanto, procurar redefinir os conceitos associados à ideia de Curadoria Digital (DUTRA; MACEDO, 2016, p.147).
\end{abstract}

Em pesquisa prática quantitativa, Duque, Shintaku e Suaiden (2015-2016) realizam a análise repositórios institucionais, verificando sua adequação aos conceitos considerados modernos de CD. No entanto, os autores compreendem que há uma diferenciação entre preservação e curadoria, atentando às questões legais de acesso:

Com relação às questões legais, McGinley (2007) relata que a curadoria digital é ampla, semelhante a uma lei, no qual as questões legais envolventes na curadoria são dependentes do estágio a que opera, nos vários tipos de usuários acessando os objetos digitais curados, nos variados níveis diferenciados de permissões. Autores diferem dos curadores, que por sua vez, diferem dos leitores (DUQUE; SHINTAKU; SUAIDEN, 2015-2016, p. 157).

Para Gatelli e Ribeiro (2015, p. 76) a Curadoria Digital fez parte referencial de um trabalho para a criação de uma ferramenta de ontologia, baseada em gestão de dados oceanográficos. De acordo com os autores, a gestão de metadados via curadoria "reduz a duplicação de esforços na criação de dados e aumenta o valor de longo prazo dos dados existentes [...] reduz ameaças ao valor de investigação de longo prazo e ainda diminui o risco de obsolescência digital”. Pinto e Sales (2017, p. 496) tem uma compreensão semelhante sobre o tema, em relação à preservação de dados de prontuários médicos. Para os autores, "a curadoria digital demanda, necessariamente, a determinação de metadados digitais". Insere-se, portanto, diretamente na área da representação temática ou indexal e descritiva da informação.

Em relação a estudos referentes à Curadoria Digital voltada para ambiente web, ou seja, Curadoria de Conteúdo, foi possível verificar uma frequência do tema referente a estudos práticos em museus e em arquivos digitais. Em ambos estudos 
de Jorente et al. (2016) e Jorente e Khan (2017) tratam do design de informação no Museu Afro e no Museu da Pessoa, respectivamente. Embora tenham objetos de pesquisa distintos, os artigos verificam a CD pelo viés da web 2.0 e seus ambientes, refletindo a preocupação com a memória digital e coletiva para a cultura brasileira. Ainda sobre museus, o artigo de Silva e Loureiro (2015) questiona a definição do termo curadoria pelo viés da museologia e o papel do próprio curador não apenas como especialista, mas como agente criador de uma visão de mundo a cara exposição curatorial.

Ainda sobre Curadoria de Conteúdo, Mansell (2014) em seu artigo realiza uma diferenciação entre Curadoria Digital e Curadoria de Conteúdo, considerando esta última como mais imediatista e menos formal que, porém, tem outras prioridades no sentido de criação. O autor compreende que as plataformas digitais para produção de conteúdo e criação de comunidades agregariam mais à resolução de problemas pela via da curadoria, em detrimento de questões de preservação, que seriam importantes em um contexto distinto. Esta compreensão vai ao encontro do entendimento que têm Jorente e Batista (2017) em relação aos arquivos permanentes do Twitter em seu estudo prático:

\begin{abstract}
Entendemos que a Curadoria Digital de acervos, em geral, e também dos acervos arquivísticos em ambiente digital, proporciona que a informação preservada nos documentos possa ser compartilhada com os internautas que visitam o ambiente e que podem se apropriar dos conteúdos e formas de apresentação da informação que ali visualizam, de maneira a empoderar-se como protagonistas do conhecimento ali representado. Note-se que, para o compartilhamento das informações são necessárias estratégias diversas daquelas utilizadas na disseminação da informação, pois aqui deve-se compreender etapas de horizontalidade, ou bottom-up, nos relacionamentos dos internautas com os ambientes digitais (JORENTE; BATISTA, 2017, p. 10, grifo nosso).
\end{abstract}

Alencar-Brayner (2016) entende a Curadoria de Conteúdo através da criação de projetos de arquivamento de páginas web no Reino Unido, pensando em um projeto que se adeque à realidade dos arquivos brasileiros, verificando os obstáculos tecnológicos e modelos curatoriais adotados para preservação e acesso ao conteúdo publicado na web. Valero (2017), especificamente a partir do contexto de bibliotecas, estuda a Curadoria de Conteúdo (web) e sua aplicabilidade e ferramentas, com foco na importância da preservação e recuperação de material a longo prazo. 
Outros artigos, apenas mencionam a Curadoria, preservando o foco no objeto principal de pesquisa. Marcondes (2016, p. 75) apenas menciona o termo quando compreende que "mais recentemente vem sendo cada vez mais empregado o termo "curadoria digital" embora com um uso um tanto quanto metafórico em relação ao significado tradicional, envolvendo a preservação dos dados de pesquisa digitais". Em seus artigos sobre competência, Boeres e Cunha (2016) e Boeres (2018) entendem a curadoria como um meio, mas não como o fim de seus argumentos, focando-se mais determinadamente em quais são as características necessárias para desenvolver competência como curador.

\section{Preservação Digital (13)}

O segundo termo mais frequente na recuperação de artigos sobre Curadoria, é a categoria de Preservação Digital. A Preservação Digital embora tenha pouca variabilidade no termo, em relação ao significado ela costuma variar entre a preservação de dados, de gestão e de conteúdo.

Santos (2016, p. 460) analisou conceitualmente a Curadoria Digital e a Preservação Digital, focando em seus pontos de interseção e diferenciação e realizando cruzamentos conceituais entre os dois termos. A autora compreende a Preservação Digital como método, processo e modelo entendendo que "tanto a curadoria quanto a preservação consideram a natureza dos objetos digitais, a sua representação e a preocupação com acesso futuro desses ativos digitais".

Santos (2016, p. 460) vai ao encontro de estudos realizados por Gonçalves e Paletta (2016) e Pavão, Caregnato e Rocha (2016), quando conclui que a Curadoria Digital é "um termo amplo utilizado para designar as atividades necessárias à gestão da informação em meio digital maiores que a preservação, ela trata da manutenção consciente e orientada à preservação e acesso dos ativos digitais resultantes da pesquisa científica".

Sayão e Sales (2013) e Sayão et al. (2017), a partir do entendimento de gestão de dados de pesquisa e uso de cadernos eletrônicos para a preservação digital em eCiência, compreendem que o papel do bibliotecário é fundamental para o 
planejamento da Preservação Digital a longo prazo. O foco no profissional da informação ocorre não somente pela gestão de novos documentos na comunicação científica, mas também para institucionalização dos dados, garantindo assim a sua confiabilidade a longo prazo.

Boeres e Cunha (2016) e Boeres (2018) discorrem sobre competências profissionais necessárias para o trabalho de curadoria digital, possuem entendimentos distintos em dois momentos. Boeres e Cunha (2016, p. 431) entendem que, embora a curadoria e a preservação tenham muitas semelhanças, "a curadoria envolve um processo mais abrangente, pois abarca a preservação desde o momento da criação dos dados. Isto engloba um amplo processo que altera o uso dos dados de pesquisa como vinha sendo feito até o momento". Para os autores:

A PD envolve o garantir que a informação digital permaneça acessível, com
autenticidade, integridade e confiabilidade, para que possa, futuramente, ser
completamente acessada, interpretada e utilizada, inclusive numa plataforma
tecnológica diferente daquela utilizada em sua criação (BOERES; CUNHA,
2016, p. 434).

Corrêa (2016) também ressalta o papel dos bibliotecários na gestão de dados científicos - quais são os critérios de seleção de repositórios, a ser realizada por bibliotecários, levando em consideração questões de preservação de dados a longo prazo. Fernandes e Oliveira (2018) pesquisam sobre um modelo ideal para PD a partir do OAIS (Open Archival Information System), porém considerando que o intermédio para o desenvolvimento da PD deve recair sobre as instituições:

\begin{abstract}
As instituições interessadas na preservação digital precisam planejar, investir e organizar-se, adotando padrões, manuais de referência, metadados e uma infraestrutura tecnológica para a preservação e formar uma rede distribuída de relacionamentos com outras instituições que também preservem acervos digitais como estratégias estruturantes (FERNANDES, OLIVEIRA, 2018, p. 260).
\end{abstract}

Neste sentido, Pinto e Sales (2017, p. 503) realizaram um estudo prático com o mesmo repositório OAIS para a preservação e utilização de prontuários médicos, via padrões de metadados. Em sua análise, os autores concluíram que a função da preservação digital, além de realizar a gestão de informações médicas, ressalta outras garantias, tais como "seus aspectos legais, além de sua autenticidade, confiabilidade, 
integridade, confidencialidade/privacidade, auditabilidade, assinatura eletrônica e devida guarda".

Em relação especificamente à Preservação Digital de conteúdo web, foram recuperados dois artigos. Alencar-Brayner (2016) visa a preservação levando em conta o ambiente da world wide web e de suas páginas, considerando questões de arquivamento. Rezende e Martins (2018) analisam a ferramenta Twitter, levando em consideração a preservação de conteúdo em mídias sociais e concluem que, embora a função comunicacional tenha sua importância, o foco principal destas iniciativas não se trata diretamente a preservação de todas as conversas disponíveis.

\section{Arquivo (5)}

A categoria de Arquivo foi a mais diversa de todas as categorias analisadas, já que possuiu vários qualificadores, a saber: Arquivo de páginas Web, Arquivos Abertos, Arquivos de Arte Visual, Arquivos Digitais e Arquivos Permanentes. Todos os tipos de arquivos possuem significados fundamentalmente distintos, o que contribui para uma compreensão mais rica do conteúdo.

Para Alencar-Brayner (2016), que trata sobre programas de arquivo de páginas web, a questão do arquivamento na CD se refere a Curadoria de Conteúdo, embora exista a preocupação com a preservação digital de páginas web. Já Fernandes e Oliveira (2018, p. 256) sugerem a utilização do Open Archival Information System (OAIS) relacionando o arquivamento à preservação de dados de pesquisa, posto que "a curadoria é efetivada através de metadados que documentam o conteúdo, dependências técnicas, proveniência, identificação persistente, ações de preservação sofridas e restrições de acesso da informação preservada".

Duque, Shintaku e Suaiden (2015-2016) e Marcondes (2016) tratam a questão de Arquivo pelo mesmo viés: o de Arquivos Abertos visando a interoperabilidade, seja entre repositórios institucionais e/ou entre acervos de arquivos, museus e bibliotecas. Já Zanella (2017) realiza um estudo comparativo entre dois arquivos de artes visuais - sendo um arquivo físico e outro digital - trazendo à tona questões referentes à documentação born digital. 


\section{Repositórios (5)}

Corrêa (2016) e Sayão e Sales (2016), ambos artigos com resultados de pesquisas práticos, trataram sobre o tema de repositórios de forma aproximada, delineando suas tipologias de acordo com o seu uso, quando em um processo de seleção. Para Sayão e Sales (2016, p. 99) os Repositórios institucionais "tem como perspectiva oferecer um ambiente dinâmico e flexível - principalmente pela natureza heterogênea dos dados - para dar apoio à execução dos processos de gestão de dados de pesquisa".

Duque, Shintaku e Suaiden (2015-2016) analisam os repositórios institucionais através de uma pesquisa prática e quantitativa, verificando até que ponto se adequam a conceitos modernos de Curadoria Digital. Segundo os autores, uma vez que os repositórios já fazem parte dos processos da comunicação científica, levantar o cenário sobre a aderência dos repositórios brasileiros frente às tendências atuais de ciência é o objetivo principal do estudo.

Similarmente, em investigação realizada em repositório específico, Medeiros (2016) verifica que a autoria de dados científicos é coordenada por uma série de elementos, entre eles a Curadoria Digital. Também compreende que a importância dos repositórios está na "possibilidade de que eles proporcionam acesso universal à grande quantidade de dados/informação científica, possibilitando que a visibilidade de autores e instituições, bem como dos próprios dados que agregam, seja potencializada", afirma Medeiros (2016, p. 312). Pavão, Caregnato e Rocha (2016) compreendem os repositórios como objeto principal da Preservação Digital, no entanto, sem realizar a sua definição.

\section{Competências (5)}

Apenas dois padrões emergiram quando da análise da categoria Competência: Competência Profissional e Competência Informacional. A princípio, conforme analisado, elas não diferem entre si em significado. Contudo, os contextos de cada artigo diferem entre competências profissionais/informacionais de/para Curadoria de 
dados (CURTY; SERAFIM, 2016), Curadoria Digital (BOERES; CUNHA, 2016; BOERES, 2018) e Curadoria de Conteúdo (VALERO, 2016). O que difere realmente entre estes três tipos de curadoria é o objeto a ser gerido: dados, itens digitais e conteúdos digitais, aferindo objetivos distintos para cada autor.

Curty e Serafim (2016, p. 312), no estudo sobre a formação de cientistas de dados pelas universidades norte americanas, complementam que "os cientistas de dados são responsáveis pela identificação, coleta, tratamento, transformação, análise, visualização e curadoria de grandes conjuntos de dados heterogêneos". Boeres e Cunha (2016) e Boeres (2018) tratam da tipologia de competências que o profissional da informação necessita para efetivar o processo de preservação digital e curadoria digital. Valero (2016) trata especificamente das competências infocomunicacionais que os bibliotecários do século XXI deverão desenvolver para realizar adequadamente a aplicação de Curadoria de Conteúdos estabelecendo um paralelo com as atribuições de bibliotecários.

\section{Biblioteca (5)}

Além do termo Biblioteca, houve a recuperação de termos específicos como também Biblioteca Universitária e Biblioteca Digital. Corrêa (2016, p. 388) em sua análise, a partir de uma perspectiva de gestão de dados científicos realizada por bibliotecários, fala das Bibliotecas Universitárias e do seu papel de mediação, uma vez que "as bibliotecas estão desenvolvendo serviços de apoio durante as fases do ciclo de vida dos dados científicos, ou seja, quando os pesquisadores estão gerando e utilizando o dados em seu plano de trabalho. Gonçalves e Paletta (2016), embora mencionem bibliotecas digitais, mantém o foco de sua pesquisa investigativa sobre 0 papel do bibliotecário, enquanto mediador entre a CD e o público, de modo geral.

Marcondes (2016) ressalta o papel das bibliotecas quando da importância da interoperabilidade entre acervos, em um artigo mais tecnicista, indo ao encontro de Martins e Silva (2017) com seus critérios de avaliação para bibliotecas digitais. Os autores compreendem que "um critério de qualidade de uma ferramenta de biblioteca digital é suportar com funcionalidades a possibilidade de ativar a inteligência coletiva de seus usuários na curadoria de conteúdo" (MARTINS; SILVA, p. 115). Valero (2016), 
ao tratar do tema de aplicabilidade e de ferramentas utilizadas na Curadoria de Conteúdo na web, cita 3 diferentes tipos de bibliotecas, como a British Library, a Biblioteca de Tradução e Documentação da Universidade de Salamanca e a Biblioteca Municipal de Muskiz (Vizcaya).

\section{Dado de Pesquisa (5)}

A categoria Dado de Pesquisa foi a única que não apresentou diversidade em sua nomenclatura. Gonçalves e Paletta (2016, p. 51) realizaram uma breve conceitualização do termo, concluindo também que:

A preservação dos dados relevantes de todo um processo de investigação científica pode, além de favorecer acesso e uso de uma coleção de dados, ressignificá-la, uma vez que, novas combinações podem ser feitas e novas funções ser dadas às nossas coleções de dados (GONÇALVES; PALETTA, 2016, p. 51).

Nos artigos de Sales e Sayão (2012a, 2013 e 2016) e Rocha, Sales e Sayão (2017) o Dado de Pesquisa foi compreendido como objeto principal que está relacionado a um tema muito mais amplo, que é a criação de políticas para a Curadoria Digital e Preservação de Dados Digitais no Brasil, via repositórios.

\section{Museus (5)}

Entre os termos da categoria Museus, foi possível encontrar 3 nomes de museus em específico, a saber: Museu da Pessoa, Museu de Arte do Rio e Museus de História Natural.

Jorente et al. (2016) e Jorente e Khan (2017) realizam análises similares em diferentes museus, levando em consideração o design da informação para o desenvolvimento de uma curadoria de conteúdo, com o foco principalmente no desenvolvimento e participação de comunidades. 
Marcondes (2016, p. 66) exemplifica a aplicação de interoperabilidade e sinergias entre arquivos, museus e bibliotecas, quando afirma que "um link semântico seria, por exemplo, ligar o registro do arquivo digital de um filme numa cinemateca digital com a imagem digital de uma pintura no acervo de um museu, que inspirou o filme".

Silva e Loureiro (2015) e Barboza e Saldanha (2018) tratam sobre o tema de Curadoria em museus de forma similar, questionando o papel do próprio curadorbibliotecário, não apenas como um especialista com competências informacionais adequadas para organizar adequadamente, mas como agente criador que se apropria de uma coleção para criar a representação de uma visão de mundo a cada decisão de exposição curatorial.

\subsubsection{Categorias Menos Frequentes}

Nas Categorias Menos Frequentes, foram encontrados tópicos de interesse que são, em certa medida, relacionados entre si tais como: e-Ciência, Acesso Aberto, Ciência Aberta e Dados Abertos - todos pertencentes aos mesmos artigos e autores. As categorias Informação e Tecnologia e Design da Informação, embora tratem de aspectos mais genéricos, também são atributos dos mesmos artigos recuperados. A categoria Outro Tema, trata-se de termos duplicados. No entanto, é interessante observar o alcance da granularidade de temas, quando o assunto é tecnologia: Acervos digitais e documentais, Big Data, Gestão de dados de pesquisa, Metadados, Twitter e Web Colaborativa.

\subsubsection{Termos Únicos}

$\mathrm{Na}$ análise terminológica, foram encontrados 43 termos únicos, que tiveram frequência de uma única vez. Trata-se de termos em sua maioria genéricos, possivelmente atribuídos aos artigos para aumentar a sua encontrabilidade via palavras-chave pelos buscadores automáticos. Após sua estruturação e organização, estes termos foram conceitualizados e agrupados em cinco subcategorias sugeridas, conforme o quadro a seguir: 
Quadro 5 - Categorias de termos únicos.

\begin{tabular}{l|l}
\hline \multicolumn{1}{c|}{ Categorias } & \multicolumn{1}{c}{ Termos Únicos } \\
\hline $\begin{array}{l}\text { Abordagens e } \\
\text { Métodos }\end{array}$ & $\begin{array}{l}\text { Ciência de Dados; Dimensões Analíticas; Ciência da Informação; } \\
\text { Comunicação Científica; Cultura; }\end{array}$ \\
\hline Objetos & $\begin{array}{l}\text { Arte Italiana; Arte Não Realizada; Autoria; Autoridade; Cadernos } \\
\text { Eletrônicos de Laboratório; Cidadania; Dados de Investigação; } \\
\text { Informação Digital; Linguagens Híbridas; Livro de Artista; Memória na } \\
\text { Internet; Mídia Social; Objetos Digitais; Perfil de Aplicação; }\end{array}$ \\
\hline Perfis & $\begin{array}{l}\text { Bibliotecários Acadêmicos; Cientista de Dados; Curador de Conteúdos; } \\
\text { Profissional Bibliotecário; }\end{array}$ \\
\hline Processos & $\begin{array}{l}\text { Ciclo de vida dos dados; Compartilhamento de Informação; Critérios de } \\
\text { Comparação; Crowdsourcing; Gestão da Informação Digital; Gestão de } \\
\text { Inclusão Social; Integração; Interoperabilidade; Práticas de Arte } \\
\text { Contemporânea; Práticas de Preservação Digital; }\end{array}$ \\
\hline Produtos & $\begin{array}{l}\text { Arquitetura da Informação; Documentação Museológica; Fontes de } \\
\text { Informação; Formação Profissional; Governança; Ontologia; Plataforma } \\
\text { Digital; }\end{array}$ \\
\hline
\end{tabular}

Os termos únicos também se encontram no Apêndice $B$, listados alfabeticamente. Somente um artigo em que todas as palavras-chaves eram termos únicos foi recuperado. Neste caso o termo Curadoria foi recuperado via texto. 


\section{CONSIDERAÇÕES FINAIS}

A realização deste projeto de pesquisa é um amadurecimento de interesses pessoais de pesquisa, advindos de estudos sobre terminologia em Organização da Informação e do Conhecimento. Como sugerido por Santos (2014) para investigações em estudos futuros, este projeto pesquisou a Curadoria em outros contextos linguísticos. Uma vez que as publicações periódicas fazem parte fundamental da comunicação científica da área, o levantamento e a identificação da produção de artigos sobre Curadoria e seus contextos trouxeram novas perspectivas para pensar de que modo os produtos, serviços e a própria atuação profissional atua no mundo.

A partir da revisão da literatura recuperada e do mapeamento do termo, a questão da ausência de uma definição unívoca em relação a Curadoria deixou, ao longo do desenvolvimento do trabalho, de ser compreendida como um problema no sentido estrito da palavra. Ao contrário do que se acreditava no início do projeto de pesquisa e na própria qualificação, esta ausência de definição não se trata de uma lacuna de conhecimento, mas sim de um campo de possibilidades e possíveis anunciações. Neste sentido, foi possível analisarmos contextos culturais de organização da informação e do conhecimento que se apropriam da curadoria como prática.

De acordo com o material recuperado e analisado, verifica-se que na área de Ciência da Informação, o termo Curadoria é intimamente relacionado ao contexto digital, uma vez que grande parte dos itens foram recuperados com o qualificador "Digital". A Curadoria Digital, no entanto, está relacionada a organização da informação e do conhecimento pois interfere diretamente nas formas em que se pensa a organização e também na forma em que ela pode ser viabilizada, através das tecnologias que dispomos na atualidade. A comunidade científica de $\mathrm{Cl}$ relaciona a Curadoria intimamente com Preservação Digital e a partir daí toda a sua cultura: repositórios em acesso livre e gestão de dados científicos.

É legítima - podendo ser compreendida inclusive como uma questão de tradição - a preocupação da área em se posicionar enquanto mediadora da informação. A Curadoria, mesmo digital, está diretamente ligada a dados, repositórios, arquivos, museus e até mesmo à própria identidade profissional e suas competências 
básicas para o desenvolvimento de um trabalho adequado. No entanto é possível verificar, mesmo que de forma ainda bastante emergente, algumas tentativas de compreensão de processos tecnológicos que viabilizam a desintermediação da informação, a saber: design da informação e web colaborativa. Ambientes mais abertos e de acesso direto, onde o papel do mediador da informação e do usuário muitas vezes se confundem, o que proporciona uma compreensão acerca de Curadoria como fonte de criação e não somente de gestão.

O digital viabilizou serviços que, num suposto organograma de determinada organização, há alguém sendo diretamente responsabilizado pela organização daquela informação em específico. Esta responsabilidade não indica a criação de uma curadoria em si, mas de uma estruturação e organização de dados ou informações. 0 ambiente digital viabiliza não só organizações feitas a partir de iniciativas de profissionais, mas também por meio dos próprios usuários por meio de tecnologias de inteligência artificial e sistemas de recomendação que podem sugerir referências de acordo com repertório pessoal.

Nesse sentido, compreendemos que tanto profissionais quanto sistemas de inteligência artificial lidam com curadoria num contexto de dados estruturados. No entanto, a Curadoria também pode ser viabilizada a partir de dados não estruturados, se formos levar em conta as informações obtidas via redes sociais ou outras plataformas.

Concluímos então que a experiência do usuário é considerada primariamente em relação ao desenvolvimento de comunidades e posteriormente em relação ao desenvolvimento de coleções: sejam dados, informações ou outros registros de conhecimento. É diretamente dependente do objetivo da Curadoria em questão, em relação aos seus usuários-fruidores, a tipologia da criação do repertório e dos resultados de sua recuperação. É preciso compreender até que ponto a Curadoria em questão permite a criação de repertórios objetivos com respostas automatizadas e precisas ou do que podemos chamar de repertórios de subjetividades - com visões de mundo, atendo-se mais ao significado do conteúdo em si do que a sua forma.

Este tipo de atitude em relação à Curadoria se relaciona com o pensamento de epistemografia integrativa de Garcia Gutierrez (2006) e de Smart Curation de Martel (2015). Entre as questões fundamentais relativas a este tipo de Curadoria voltada para 
web (seus produtos, processos e definições) a questão da necessidade de colaboração entre curadores profissionais e não-especialistas - e seus objetivos - é o que auxilia em sua definição. A questão é abordada de forma diferenciada uma vez que a partir da perspectiva de gestão pensamos em possibilidades de acesso e na perspectiva de criação, pensa-se em disseminação e compartilhamento, independente do meio.

Finalmente, os tipos de Curadoria, sejam elas autorais ou filtros, visam uma interdependência da qual todos os processos, produtos e serviços não podem se permitir escapar para serem inteligíveis - sejam por máquinas ou humanos. Embora caminhe-se para um futuro automatizado em uma provável tecnocracia ascendente, as decisões em relação à curadoria levarão em conta o hibridismo, que, por sua vez sempre partirá do conhecimento e da criação humanas.

Profissionais que lidam diretamente com variados tipos de informação, criando e tendo iniciativas próprias de processos de curadorias únicos, visam muitas vezes empoderar e conceder autonomia a usuários - ao mesmo passo em que planejam o desenvolvimento de coleções. Acredito que uma terceira via, entre a curadoria e o processo de organização da informação digital seja sim possível, no entanto a questão do engajamento de comunidades seria essencial para qualquer serviço nesse sentido. Entre o zelo e a catarse, cabe verificarmos de qual forma pretendemos ressignificar o uso, o entendimento e o afeto das informações que utilizamos e dos conhecimentos que criamos e apresentamos ao mundo. 


\section{REFERÊNCIAS}

ALENCAR-BRAYNER, A. Programa de arquivo de páginas web no reino unido: Uma breve história de oportunidades e desafios. Revista Digital de Biblioteconomia e Ciência da Informação, Campinas, v. 14, n.2, p. 318-333, mai./ago. 2016.

Disponível em:

https://periodicos.sbu.unicamp.br/ojs/index.php/rdbci/article/view/8645982/pdf.

Acesso em: 3 mar. 2018.

ARAUJO, R. F.; STEIMER, I. S. G. Análise da Informação. In: Tarcízio Silva; Max Stabile. (Orgs.). Monitoramento e pesquisa em mídias sociais: metodologias, apli cações e inovações. São Paulo: Uva Limão, 2016.

BARBOZA, A. S. SALDANHA, G. S. O livro de artista, o colecionador e a coleção no museu: um itinerário intersubjetivo da coleção de livros de artista de Paulo Herkenhoff no Museu de Arte do Rio. InCID: Revista de Ciência da Informação e Documentação, Ribeirão Preto, v. 8, n. 2, p. 176-191, set. 2017/fev. 2018. Disponível em: https://www.revistas.usp.br/incid/article/view/133575/133894. Acesso em: 3 mar 2018

BARDIN, L. Análise de conteúdo. Lisboa: Edições 70, 2010.

BAZI, R. E. R.; SILVEIRA, M. A. A. Constituição e institucionalização da ciência: apontamentos para uma discussão. Transinformação, Campinas, v. 19, n. 2, p. 129-137, maio/ago. 2007. Disponível em: http://revistas.puccampinas.edu.br/transinfo/viewarticle.php?id=253. Acesso em: 13 set. 2016.

BOERES, S. CUNHA, M. B. Competências para a preservação e curadoria digitais. Revista Digital de Biblioteconomia e Ciência da Informação, Campinas, v. 14, n. 3, p. 426-449, set./dez. 2016. Disponível em:

https://periodicos.sbu.unicamp.br/ojs/index.php/rdbci/article/view/8646303/pdf.

Acesso em: 3 mar. 2018.

BOERES, S. A. S. Quem está preservando seus dados digitais? Estaria surgindo uma nova profissão? Revista Ibero-Americana de Ciência da Informação, Brasília, v. 11, n. 1, p. 149-167, jan./abril. 2018. Disponível em:

http://periodicos.unb.br/index.php/RICl/article/view/27923/20185. Acesso em: 3 mar. 2018.

BRADBURY, R. Fahrenheit 451. São Paulo: Globo, 2009.

BRASIL. Classificação Brasileira de Ocupações: CBO - 2019. Disponível em: http://www.mtecbo.gov.br/cbosite/pages/pesquisas/BuscaPorTituloResultado.jsf Acesso em: 15 jun 2019

BRÄSCHER, M.; CAFÉ, L. Organização da Informação ou Organização do Conhecimento? In: LARA, M. L. G.; SMIT, J. (Orgs.). Temas de Pesquisa em Ciência da Informação no Brasil. São Paulo: Escola de Comunicações e Artes/USP, 2010. Disponível em: 
http://www3.eca.usp.br/sites/default/files/form/ata/pos/ppgci/publicacoes\%20\%20temasdepesquisas.pdf. Acesso em: 22 jul. 2017.

BRUCE, C. MIDDLETON, M. Teaching and learning information organization: the Queensland University of Technology experience. Cataloguing Australia, v. 22, n.12, 1996, p. 34-47

BUCKLAND, M. K. Naming in the library: Marks, meaning and machines. In: TODENHAGEN, C.; THIELE, W. (Eds.) Nominalization, nomination and naming in texts. Tübingen, Germany: Stauffenburg, 2007. Disponível em:

http://people.ischool.berkeley.edu/ buckland/naminglib.pdf. Acesso em: 22 jul. 2017.

. Information as thing. Journal of the American Society of Information

Science, v. 42, n. 5, p. 351-360, jun. 1991. Disponível em:

http://ppggoc.eci.ufmg.br/downloads/bibliografia/Buckland1991.pdf. Acesso em: 22 jul. 2017.

What kind of science Can Information Science be? Journal of

Information Science and Technology, v. 63, n. 1, 2012, p. 1-7. Disponível em: http://people.ischool.berkeley.edu/ buckland/whatsci.pdf Acesso em: 22 jul 2017

CORREA, E. S.; BERTOCCHI, D. O algoritmo curador: o papel do comunicador num cenário de curadoria algorítmica de informação. In: ENCONTRO ANUAL DA COMPÓS, 21., Universidade Federal de Juiz de Fora, 12-15 jun. 2012. Associação Nacional dos Programas de Pós-Graduação em Comunicação, 2012. Anais eletrônico... Disponível em:

http://bibliodigital.unijui.edu.br:8080/xmlui/bitstream/handle/123456789/2852/Elizabe th\%20Saad\%20Corr\%C3\%AAa.pdf?sequence=1. Acesso em: 10 set. 2016.

COUTO, M. Línguas que não sabemos que sabíamos. In: E se Obama fosse africano? e outras interinvenções: ensaios. São Paulo: Cia das Letras, 2011. p. 11-24.

CURTY, R. G. SERAFIM, J. S. A formação em ciência de dados: uma análise preliminar do panorama estadunidense. Informação \& Informação, Londrina, v. 21, n. 2, p. 307-328, maio/ago., 2016. Disponível em:

http://www.uel.br/revistas/uel/index.php/informacao/article/view/27945/20195.

Acesso em: 3 mar. 2018.

DCC. DIGITAL CURATION CENTRE. DCC Curation Lifecycle Model Edinburgh: University of Edinburgh, c2004-2016b. Disponível em:

http://www.dcc.ac.uk/resources/curation-lifecycle-model Acesso em: 10 jun 2019.

DUQUE, C. SHINTAKU, M. SUAIDEN, E. J. Análise da adesão às tendências da Ciência pelos repositórios institucionais brasileiros. InCID: Revista de Ciência da Informação e Documentação. Ribeirão Preto, v. 6, n. 2, p. 148-169, set. 2015/fev. 2016. Disponível em: https://www.revistas.usp.br/incid/article/view/89191/103994. Acesso em: 3 mar. 2018.

DUTRA, M. L. MACEDO, D. D. J. Curadoria digital: proposta de um modelo para curadoria digital em ambientes big data baseado numa abordagem semi-automática 
para a seleção de objetos digitais. Informação \& Informação, Londrina, v. 21, n. 2, p. 143-169, maio/ago., 2016. Disponível em:

http://www.uel.br/revistas/uel/index.php/informacao/article/view/27176/20125.

Acesso em: 3 mar. 2018.

FAULSTICH, E. A Socioterminologia na Comunicação Científica e técnica. Ciência e Cultura, São Paulo, v. 58, n. 2, p. 27-31, abr./jun. 2006. Disponível em:

http://cienciaecultura.bvs.br/pdf/cic/v58n2/a12v58n2.pdf. Acesso em: 10 set. 2016.

FERNANDES, H. D. H. OLIVEIRA, A. F. Gestão da Preservação digital em repositórios de dados de pesquisa. Revista Ibero-Americana de Ciência da Informação, Brasília, v. 11, n. 1, p. 255-273, jan./abril. 2018. Disponível em: http://periodicos.unb.br/index.php/RICl/article/view/27902/20191. Acesso em: 3 mar. 2018.

FONSECA E SÁ, M. I.; PINHEIRO, S. G. Arquitetura de Informação no Comércio Eletrônico: a Informação como um Direito do Consumidor. In: CỎNFERÊNCIA INTERNACIONAL SOBRE SISTEMAS DE INFORMAÇÃO E GESTÃO DE TECNOLOGIA - CONTECSI, 12., São Paulo, 20-22 maio 2015. Paperview... Disponível em:

http://www.contecsi.fea.usp.br/envio/index.php/contecsi/12CONTECSI/paper/view/24 50/2261. Acesso em: 09 set. 2015.

GARRIDO, I. S. Organização da Informação: abordagens nas teses e dissertações em Ciência da Informação no Brasil. 2011. Trabalho de Conclusão de Curso (Graduação em Biblioteconomia) - Centro de Ciências da Educação, Universidade Federal de Santa Catarina, Florianópolis, 2011. Disponível em:

https://pt.slideshare.net/doritchka/tcc-revisado-11dez2011. Acesso em: 4 maio 2017.

GARCÍA GUTIÉRREZ, A. Cientificamente favelados: uma visão crítica do conhecimento a partir da epistemografia. Transinformação, Campinas, v. 18, n. 2, p.103-112, maio/ago. 2006. Disponível em: http://periodicos.puccampinas.edu.br/seer/index.php/transinfo/article/view/672. Acesso em 4 maio 2017.

GATELLI, R. T. RIBEIRO, M. C. C. A. Gestão de dados de investigação no domínio da oceanografia biológica: criação e avaliação de um perfil de aplicação baseado em ontologia. Ponto de Acesso, Salvador, v. 9, n.3, p.74-102, dez. 2015. Disponível em: https://portalseer.ufba.br/index.php/revistaici/article/view/15160/10326. Acesso em: 3 mar. 2018.

GIL, A. C. Como elaborar projetos de pesquisa. 4. ed. São Paulo: Atlas, 2002.

GOLDSMITH, K. Archiving is the new folk art. Poetry Foundation, 2011. Disponível em: https://www.poetryfoundation.org/harriet/2011/04/archiving-is-the-new-folk-art/. Acesso em: 14 set. 2016.

GONÇALVES, V. J. S. PALLETA, F. C. Curadoria digital o papel das bibliotecas na sociedade em rede Pesquisa Brasileira em Ciência da Informação e

Biblioteconomia, João Pessoa, v. 11, n. 2, p. 047-058, 2016. Disponível em: http://periodicos.ufpb.br/index.php/pbcib/article/view/29943/1615. Acesso em: 3 mar. 2018. 
GRACIOSO, L. de S. SALDANHA, G. S. Ciência da Informação e Filosofia da Linguagem: da pragmática informacional à web pragmática. Araraquara: Junqueira\&Marin, 2011. $160 \mathrm{p}$.

JACOB, E. K. Classification and Categorization: a Difference that Makes a Difference. Library Trends, v. 52, n. 3, p. 515-540, 2004. Disponível em: https://www.ideals.illinois.edu/bitstream/handle/2142/1686/Jacob515540.pdf?sequen $\mathrm{ce}=2$. Acesso em 4 maio 2017.

JORENTE, M. J. V. BATISTA, L. S. Conversações entre a rede social twitter e os arquivos permanentes: um estudo de curadoria digital. Informação \& Informação, Londrina, v. 22, n. 1, p. 05-33, jan./abr., 2017. Disponível em: http://www.uel.br/revistas/uel/index.php/informacao/article/view/23466/21049. Acesso em: 3 mar. 2018.

JORENTE, M. J. V. NAKANO, N. BATISTA, L. S. RODRIGUES, N. L. F. O design da informação na criação de um modelo para o museu afro brasil um estudo comparativo Brazilian Journal of Information Studies: Research Trends. v. 10, n. 1, p. 65-73, 2016. Disponível em:

http://www2.marilia.unesp.br/revistas/index.php/bjis/article/view/6042/4172. Acesso em: 3 mar. 2018.

JORENTE, M. J. V. KAHN, K. O Papel do Design da Informação na Curadoria Digital do Museu da Pessoa. InCID: Revista de Ciência da Informação e Documentação, Ribeirão Preto, v. 7, n. 2, p. 23-39, set. 2016/fev. 2017. Disponível em: https://www.revistas.usp.br/incid/article/view/110232/118484. Acesso em: 3 mar. 2018.

JOUDREY, D. N. A New Look at US Graduate Courses in Bibliographic Control. In: HILL, J. S. Education for cataloging and the organization of information: Pitfalls and the Pendulum. Binghamton: Haworth Press, 2002, p. 59-101.

KRUG, S. Don't make me think. New Riders Press: San Francisco, 2005. 216 p.

MACHADO, K. C.; VIANNA, W. Curadoria Digital e Ciência da Informação: correlações conceituais relevantes para apropriação da informação. In: ENCONTRO NACIONAL DE PESQUISA EM PÓS-GRADUAÇÃO EM CIÊNCIA DA INFORMAÇÃO, 17., Salvador, 2016. Anais... Salvador: UFBA, 2016. p. 1-18. Disponível em: http://200.20.0.78/repositorios/handle/123456789/3121. Acesso em: 03 jul. 2017.

MAI, J. E. Marginalization and exclusion: unraveling systemic bias of classification. Knowledge Classification, v. 43, n. 5, p. 324-330, 2016. Disponível em: http://jenserikmai.info/Papers/2016 festschrift.pdf. Acesso em: 03 jul. 2017.

MARCONDES, C. H. Interoperabilidade entre acervos digitais de arquivos, bibliotecas e museus: potencialidades das tecnologias de dados abertos interligados. Perspectivas em Ciência da Informação, v.21, n.2, p.61-83, abr./jun. 2016. Disponível em: http://portaldeperiodicos.eci.ufmg.br/index.php/pci/article/view/2735/1748. Acesso em: 3 mar. 2018. 
MÁRDERO ARELLANO, M. A. Critérios para a preservação digital da informação científica. 2008. 354 f. Tese (Doutorado) - Universidade de Brasília. Disponível em: http://repositorio.unb.br/bitstream/10482/1518/1/2008 MiguelAngelMarderoArellano. pdf. Acesso em: 3 set. 2016.

MARTEL, F. Smart Curation. In: MARTEL, F. Smart. Rio de Janeiro: Civilização Brasileira, 2015. p. 255-322.

MARTINS, D. L. SILVA, M. F. Critérios de avaliação para sistemas de bibliotecas digitais: uma proposta de novas dimensões analíticas. InCID: Revista de Ciência da Informação e Documentação, Ribeirão Preto, v. 8, n. 1, p. 100-121, mar./ago. 2017. Disponível em: https://www.revistas.usp.br/incid/article/view/125678/127737. Acesso em: 3 mar. 2018.

MANSELL, R. Colaboração aberta para a solução de problemas sociais: normas de autoridade de governança convergentes ou divergentes? Liinc em Revista, Rio de Janeiro, v.10, n.2, p. 451-459, nov./2014. Disponível em:

http://revista.ibict.br/liinc/article/view/3594/3073. Acesso em: 3 mar. 2018.

MAZZOCCHI, F. Images of thought and their relation to classification: the tree and the net. Knowledge Organization, v. 40, n. 6, p. 366-374, 2013.

MCLUHAN, Marshall. Os meios de comunicação como extensões do homem. São Paulo: Cultrix, 1969. 407 p.

MEDEIROS, J. S. Uma investigação sobre a autoria de dados científicos: Teias de uma rede em construção. Revista Digital de Biblioteconomia e Ciência da Informação, Campinas, v. 14, n.2, p. 298-317, maio/ago. 2016. Disponível em: https://periodicos.sbu.unicamp.br/ojs/index.php/rdbci/article/view/8644015/pdf. Acesso em: 3 mar. 2018.

MERLO VEGA, J. A. La biblioteca como "community manager" y "content curator" (1/2). El ciclo de la gestión de comunidades y contenidos. BiblioBlog, 22 mar. 2014. Disponível em: https://biblioblog.org/2014/03/22/biblioteca-comunidades-contenidos/. Acesso em: 25 jul. 2017.

MORVILLE, P. ROSENFELD, L. Chapter 5: Organization Systems. In: MORVILLE, P. ROSENFELD, L. Information Architecture for the world wide web. 3. ed. Califórnia: O'Reilly, 2006.

MOSTAFÁ, S.P. Ciência da Informação: uma ciência, uma revista. Ciência da Informação, Brasília v. 25, n. 3, 1996. Disponível em: http://revista.ibict.br/index.php/ciinf/article/view/448/407. Acesso em: 19 nov. 2011.

OLSON, H. Review article: classification and universality application and construct. Semiotica, v. 139, n. 1-4, p. 377-391, 2002.

PALMER, A. The Art of Asking. Grand Central Publishing: New York. 2014.

PAVÃO, C. G. CAREGNATO, S. E. ROCHA, R. P. Implementação da preservação digital em repositórios: conhecimento e práticas. Revista Digital de 
Biblioteconomia e Ciência da Informação, Campinas, v. 14, n.3, p. 407-425, set./dez. 2016. Disponível em:

https://periodicos.sbu.unicamp.br/ojs/index.php/rdbci/article/view/8646326/pdf.

Acesso em: 3 mar. 2018.

PINTO, V. B. SALES, O. M. M. Proposta de aplicabilidade da preservação digital ao prontuário eletrônico do paciente. Revista Digital de Biblioteconomia e Ciência da Informação, Campinas, v. 15, n.2, p. 489-507, maio/ago. 2017. Disponível em: https://periodicos.sbu.unicamp.br/ojs/index.php/rdbci/article/view/8646311/pdf.

Acesso em: 3 mar. 2018.

RANGANATHAN, S. R. As cinco leis da Biblioteconomia. Brasília: Briquet de Lemos Livros, 2009.

REZENDE, L. V. R. MARTINS, D. L. Iniciativas científicas de arquivamento e preservação de conteúdos em mídias sociais: panorama atual. Revista IberoAmericana de Ciência da Informação, Brasília, v. 11, n. 1, p. 219-236, jan./abril 2018. Disponível em:

http://periodicos.unb.br/index.php/RICl/article/view/27892/20189. Acesso em: 3 mar. 2018.

ROCHA, L. L. SALES, L. F. SAYÃO, L. F. Uso de cadernos eletrônicos de laboratório para as práticas de ciência aberta e preservação de dados de pesquisa. Ponto de Acesso, Salvador, v. 11, n.3, p.2-16, dez./2017. Disponível em:

https://portalseer.ufba.br/index.php/revistaici/article/view/24945/15542. Acesso em: 3 mar. 2018.

SALES, L. F.; SAYÃO, L. F. O impacto da Curadoria Digital dos Dados de Pesquisa na Comunicação Científica. Encontros Bibli: Revista eletrônica de Biblioteconomia e Ciência da Informação, v. 17, n. esp. 2 - III SBCC, p.118-135, 2012. Disponível em: https://periodicos.ufsc.br/index.php/eb/article/view/1518-

2924.2012v17nesp2p118. Acesso em: 2 set. 2016.

SALES, L. F. SAYÃO, L. F. Curadoria digital: um novo patamar para preservação de dados digitais de pesquisa. Informação e Sociedade: Estudos. João Pessoa, v.22, n.3, p. 179-191, set./dez. 2012a. Disponível em:

http://www.ies.ufpb.br/ojs2/index.php/ies/article/view/12224/8586. Acesso em: 3 mar. 2018.

SALES, L. F. SAYÃO, L. F. Algumas considerações sobre os repositórios digitais de dados de pesquisa. Informação \& Informação, Londrina, v. 21, n. 2, p. 90-115, maio/ago., 2016. Disponível em:

http://www.uel.br/revistas/uel/index.php/informacao/article/view/27939/20122.

Acesso em: 3 mar. 2018.

SANTOS, T. N. C. Curadoria Digital: o conceito no período de 2000 a 2013. 2014. 165 f. Dissertação (Mestrado) - Universidade de Brasília, 2014. Disponível em: http://repositorio.unb.br/bitstream/10482/17324/1/2014 ThayseNataliaCantanhedeSa ntos.pdf. Acesso em: 3 set. 2016.

SANTOS, T. N. C. Curadoria digital e preservação digital: cruzamentos conceituais. Revista Digital de Biblioteconomia e Ciência da Informação, Campinas, v. 14, 
n.3, p. 450-464, set./dez. 2016. Disponível em:

https://periodicos.sbu.unicamp.br/ojs/index.php/rdbci/article/view/8646336/pdf.

Acesso em: 3 mar. 2018.

SARACEVIC, T. Interdisciplinary nature of Information Science. Ciência da Informação, v. 24, n. 1, p. 1-9, 1995. Disponível em:

http://dici.ibict.br/archive/00000598/01/natureza interdisciplinar.pdf. Acesso em: 5 abr. 2011.

SAYÃO, L. S. F.; SALES, L. F. Dados de pesquisa: contribuição para o estabelecimento de um modelo de curadoria digital para o país. Tendências da Pesquisa Brasileira em Ciência da Informação, v. 6, n. 1, 2013. Disponível em: http://www.brapci.inf.br/v/a/14157. Acesso em: 10 abr. 2018.

SILVA, S. D. LOUREIRO, J. M. M. Informação, memória e processos curatoriais: disrupções e diafanizações nos museus de história natural. Tendências da Pesquisa Brasileira em Ciência da Informação, v.8, n.2, p. 280-300, jul./dez. 2015. Disponível em: http://inseer.ibict.br/ancib/index.php/tpbci/article/view/210/275. Acesso em: 6 mar. 2018.

SOUZA, R. F. STUMPF, I. R. C. Ciência da Informação como área do conhecimento: abordagem no contexto da pesquisa e da Pós-Graduação no Brasil. Perspectivas em Ciência da Informação, v. 14, número especial, p. 41-58, 2009. Disponível em: http://portaldeperiodicos.eci.ufmg.br/index.php/pci/article/viewFile/901/606. Acesso em: 5 abr. 2011.

STEIMER, I. S. G.; LUZ, C. S. Taxonomia para comércio eletrônico: diferentes perspectivas em front e back end. Ciência da Informação em Revista, v. 2, p. 3-14, 2015. Disponível em: http://www.seer.ufal.br/index.php/cir/article/view/2186. Acesso em: 2 set. 2016.

SVENONIUS, E. The Intellectual Foundations of Information Organization. Cambridge: The MIT Press, 2000. 255 p.

SHIRKY, C. Ontology is Overrated: categories, links and tags. In: SHIRKY, C. Clay Shirky's Writings About the Internet: Economics \& Culture, Media \& Community. 2005. Disponível em:

http://www.shirky.com/writings/ontology overrated.html?goback=.gde 1838701 me mber 179729766. Acesso: 27 set. 2016.

SIEBRA, S. A.; BORBA, V.; MIRANDA, M. K. F. O. Curadoria Digital: um termo interdisciplinar. In: ENCONTRO NACIONAL DE PESQUISA EM PÓSGRADUAÇÃO EM CIÊNCIA DA INFORMAÇÃO, 17., Salvador, 2016. Anais eletrônico... Salvador: UFBA, 2016. p. 1-17. Disponível em: http://www.periodicos.ufpb.br/index.php/itec/article/view/38408. Acesso em: 05 jul. 2018.

TÁLAMO, M. F. G. M.; SMIT, J. W. Ciência da Informação: pensamento informacional e integração disciplinar. Brazilian Journal of Information Science, v. 1, n. 1, p. 33-57, 2007. Disponível em: https://dialnet.unirioja.es/descarga/articulo/4366076/1.pdf. Acesso em: 05 jul. 2019. 
VALERO, P. P. Curación de contenidos desde bibliotecas competencias, herramientas y aplicaciones. Ciência da Informação, Brasília, DF, v.45 n. 2, p.103117, maio/ago. 2016. Disponível em:

http://revista.ibict.br/ciinf/article/view/3805/3359. Acesso em: 3 mar. 2018.

VELLUCCI, S. L. Future Catalogues: essential colleagues or anachronisms? College and Research Libraries News, v. 57, n. 7, jul./aug. 1996, p. 442-443.

WEINBERGER, David. Nova Desordem Digital. Rio de Janeiro: Elsevier, 2007. 273 p.

WITTGENSTEIN, Ludwig. Tractatus Logico-Philosophicus. Trad. José Arthur Giannotti. São Paulo: Companhia Editor Nacional/ Editora da Universidade de São Paulo, 1968. 
APÊNDICES 


\section{APÊNDICE A \\ Artigos sobre Curadoria Recuperados}

ALENCAR-BRAYNER, A. Programa de arquivo de páginas web no reino unido: Uma breve história de oportunidades e desafios. Revista Digital de Biblioteconomia e Ciência da Informação, Campinas, v. 14, n.2, p. 318-333, mai./ago. 2016. Disponível em: https://periodicos.sbu.unicamp.br/ojs/index.php/rdbci/article/view/8645982/pdf. Acesso em: 3 mar. 2018.

BARBOZA, A. S. SALDANHA, G. S. O livro de artista, o colecionador e a coleção no museu: um itinerário intersubjetivo da coleção de livros de artista de Paulo Herkenhoff no Museu de Arte do Rio. InCID: Revista de Ciência da Informação e Documentação, Ribeirão Preto, v. 8, n. 2, p. 176-191, set. 2017/fev. 2018.

Disponível em: https://www.revistas.usp.br/incid/article/view/133575/133894. Acesso em: 3 mar 2018.

BOERES, S. A. S. Quem está preservando seus dados digitais? Estaria surgindo uma nova profissão? Revista Ibero-Americana de Ciência da Informação, Brasília, v. 11, n. 1, p. 149-167, jan./abril. 2018. Disponível em:

http://periodicos.unb.br/index.php/RICl/article/view/27923/20185. Acesso em: 3 mar. 2018.

BOERES, S. CUNHA, M. B. Competências para a preservação e curadoria digitais. Revista Digital de Biblioteconomia e Ciência da Informação, Campinas, v. 14, n. 3, p. 426-449, set./dez. 2016. Disponível em: https://periodicos.sbu.unicamp.br/ojs/index.php/rdbci/article/view/8646303/pdf. Acesso em: 3 mar. 2018.

CASSOTA, M. L. J. LUCAS, A. BLATTMANN, U. GODOY VIERA, A. F. Recursos do conhecimento: colaboração, participação e compartilhamento de informação científica e acadêmica. Informação e Sociedade: Estudos, João Pessoa, v.27, n.1, p. 17-34, jan./abr. 2017. Disponível em:

http://www.ies.ufpb.br/ojs2/index.php/ies/article/view/29469/17409. Acesso em: 3 mar. 2018.

CONCEIÇÃO, B. B. S. CABRAL, M. G. A documentação museológica do acervo documental do estilista paraense André Lima. Revista Brasileira de Biblioteconomia e Documentação. São Paulo, v. 12, n. especial, p. 215-218, jul./dez. 2016. Disponível em: https://rbbd.febab.org.br/rbbd/article/view/618/527. Acesso em: 3 mar. 2018.

CORRÊA, F. C. O papel dos bibliotecários na gestão de dados científicos. Revista Digital de Biblioteconomia e Ciência da Informação. Campinas, v. 14, n. 3, p. 387-406, set./dez. 2016. Disponível em:

https://periodicos.sbu.unicamp.br/ojs/index.php/rdbci/article/view/8646333/pdf 1 Acesso em 3 de mai. 2019

CURTY, R. G. SERAFIM, J. S. A formação em ciência de dados: uma análise preliminar do panorama estadunidense. Informação \& Informação, Londrina, v. 21, 
n. 2, p. 307-328, maio/ago., 2016. Disponível em:

http://www.uel.br/revistas/uel/index.php/informacao/article/view/27945/20195.

Acesso em: 3 mar. 2018.

DUTRA, M. L. MACEDO, D. D. J. Curadoria digital: proposta de um modelo para curadoria digital em ambientes big data baseado numa abordagem semi-automática para a seleção de objetos digitais. Informação \& Informação, Londrina, v. 21, n. 2, p. 143-169, maio/ago., 2016. Disponível em:

http://www.uel.br/revistas/uel/index.php/informacao/article/view/27176/20125.

Acesso em: 3 mar. 2018.

FERNANDES, H. D. H. OLIVEIRA, A. F. Gestão da Preservação digital em repositórios de dados de pesquisa. Revista lbero-Americana de Ciência da Informação, Brasília, v. 11, n. 1, p. 255-273, jan./abril. 2018. Disponível em: http://periodicos.unb.br/index.php/RICl/article/view/27902/20191. Acesso em: 3 mar. 2018.

GATELLI, R. T. RIBEIRO, M. C. C. A. Gestão de dados de investigação no domínio da oceanografia biológica: criação e avaliação de um perfil de aplicação baseado em ontologia. Ponto de Acesso, Salvador, v. 9, n.3, p.74-102, dez. 2015. Disponível em: https://portalseer.ufba.br/index.php/revistaici/article/view/15160/10326. Acesso em: 3 mar. 2018.

JORENTE, M. J. V. BATISTA, L. S. Conversações entre a rede social twitter e os arquivos permanentes: um estudo de curadoria digital. Informação \& Informação, Londrina, v. 22, n. 1, p. 05-33, jan./abr., 2017. Disponível em: http://www.uel.br/revistas/uel/index.php/informacao/article/view/23466/21049. Acesso em: 3 mar. 2018.

. KAHN, K. O Papel do Design da Informação na Curadoria Digital do Museu da Pessoa. InCID: Revista de Ciência da Informação e Documentação, Ribeirão Preto, v. 7, n. 2, p. 23-39, set. 2016/fev. 2017. Disponível em: https://www.revistas.usp.br/incid/article/view/110232/118484. Acesso em: 3 mar. 2018.

. PIMENTA, R. M. SILVA, A. R. Cultura, memória e curadoria digital na plataforma SNIIC. Liinc em Revista, Rio de Janeiro, v.11, n.1, p. 122-139, maio/2015. Disponível em: http://revista.ibict.br/liinc/article/view/3637/3101. Acesso em: 3 mar. 2018.

. NAKANO, N. BATISTA, L. S. RODRIGUES, N. L. F. O design da informação na criação de um modelo para o museu afro brasil um estudo comparativo Brazilian Journal of Information Studies: Research Trends. v. 10, n. 1, p. 65-73, 2016. Disponível em:

http://www2.marilia.unesp.br/revistas/index.php/bjis/article/view/6042/4172. Acesso em: 3 mar. 2018.

. CALDAS, R. F. SILVA, R. C. Integração da Competência em Informação no contexto das bibliotecas vivas. Revista Ibero-Americana de Ciência da Informação, Brasília, v. 10, n. 2, p. 275-294, jul./dez. 2017. Disponível em: http://periodicos.unb.br/index.php/RICl/article/view/18802/18632. Acesso em: 3 mar. 2018. 
MANSELL, R. Colaboração aberta para a solução de problemas sociais: normas de autoridade de governança convergentes ou divergentes? Liinc em Revista, Rio de Janeiro, v.10, n.2, p. 451-459, nov./2014. Disponível em:

http://revista.ibict.br/liinc/article/view/3594/3073. Acesso em: 3 mar. 2018.

MARCONDES, C. H. Interoperabilidade entre acervos digitais de arquivos, bibliotecas e museus: potencialidades das tecnologias de dados abertos interligados. Perspectivas em Ciência da Informação, v.21, n.2, p.61-83, abr./jun. 2016. Disponível em: http://portaldeperiodicos.eci.ufmg.br/index.php/pci/article/view/2735/1748. Acesso em: 3 mar. 2018.

MARTINS, D. L. SILVA, M. F. Critérios de avaliação para sistemas de bibliotecas digitais: uma proposta de novas dimensões analíticas. InCID: Revista de Ciência da Informação e Documentação, Ribeirão Preto, v. 8, n. 1, p. 100-121, mar./ago. 2017. Disponível em: https://www.revistas.usp.br/incid/article/view/125678/127737. Acesso em: 3 mar. 2018.

MEDEIROS, J. S. Uma investigação sobre a autoria de dados científicos: Teias de uma rede em construção. Revista Digital de Biblioteconomia e Ciência da Informação, Campinas, v. 14, n.2, p. 298-317, maio./ago. 2016. Disponível em: https://periodicos.sbu.unicamp.br/ojs/index.php/rdbci/article/view/8644015/pdf. Acesso em: 3 mar. 2018.

PALLETA, F. C. GONÇALVES, V. J. S. Curadoria digital o papel das bibliotecas na sociedade em rede Pesquisa Brasileira em Ciência da Informação e

Biblioteconomia, João Pessoa, v. 11, n. 2, p. 047-058, 2016. Disponível em: http://periodicos.ufpb.br/index.php/pbcib/article/view/29943/1615. Acesso em: 3 mar. 2018.

PAVÃO, C. G. CAREGNATO, S. E. ROCHA, R. P. Implementação da preservação digital em repositórios: conhecimento e práticas. Revista Digital de Biblioteconomia e Ciência da Informação, Campinas, v. 14, n.3, p. 407-425, set./dez. 2016. Disponível em:

https://periodicos.sbu.unicamp.br/ojs/index.php/rdbci/article/view/8646326/pdf. Acesso em: 3 mar. 2018.

PINTO, V. B. SALES, O. M. M. Proposta de aplicabilidade da preservação digital ao prontuário eletrônico do paciente. Revista Digital de Biblioteconomia e Ciência da Informação, Campinas, v. 15, n.2, p. 489-507, maio/ago. 2017. Disponível em: https://periodicos.sbu.unicamp.br/ojs/index.php/rdbci/article/view/8646311/pdf. Acesso em: 3 mar. 2018.

REZENDE, L. V. R. MARTINS, D. L. Iniciativas científicas de arquivamento e preservação de conteúdos em mídias sociais: panorama atual. Revista IberoAmericana de Ciência da Informação, Brasília, v. 11, n. 1, p. 219-236, jan./abril 2018. Disponível em:

http://periodicos.unb.br/index.php/RICl/article/view/27892/20189. Acesso em: 3 mar. 2018.

SANTOS, T. N. C. Curadoria digital e preservação digital: cruzamentos conceituais. Revista Digital de Biblioteconomia e Ciência da Informação, Campinas, v. 14, 
n.3, p. 450-464, set./dez. 2016. Disponível em:

https://periodicos.sbu.unicamp.br/ojs/index.php/rdbci/article/view/8646336/pdf.

Acesso em: 3 mar. 2018.

SALES, L. F. SAYÃO, L. F. Curadoria digital: um novo patamar para preservação de dados digitais de pesquisa. Informação e Sociedade: Estudos. João Pessoa, v.22, n.3, p. 179-191, set./dez. 2012a. Disponível em:

http://www.ies.ufpb.br/ojs2/index.php/ies/article/view/12224/8586. Acesso em: 3 mar. 2018.

- O impacto da curadoria digital dos dados de pesquisa na

Comunicação Científica. Encontros Bibli: Revista Eletrônica em Biblioteconomia e Ciência da Informação, v. 17, n. esp. 2 - III SBCC, p.118-135, 2012b. Disponível em: https://periodicos.ufsc.br/index.php/eb/article/view/1518-

2924.2012v17nesp2p118/23573. Acesso em: 3 mar. 2018.

Dados de pesquisa: contribuição para o estabelecimento de um modelo de curadoria digital para o país. Tendências da Pesquisa Brasileira em Ciência da Informação, v. 6, n. 1, 2013. Disponível em:

http://www.brapci.inf.br/v/a/14157. Acesso em: 10 abr. 2018.

Algumas considerações sobre os repositórios digitais de dados de

pesquisa. Informação \& Informação, Londrina, v. 21, n. 2, p. 90-115, maio/ago., 2016. Disponível em:

http://www.uel.br/revistas/uel/index.php/informacao/article/view/27939/20122.

Acesso em: 3 mar. 2018

SAYÃO, L. F. ROCHA, L. L. SALES, L. F. Uso de cadernos eletrônicos de laboratório para as práticas de ciência aberta e preservação de dados de pesquisa. Ponto de Acesso, Salvador, v. 11, n.3, p.2-16, dez./2017. Disponível em:

https://portalseer.ufba.br/index.php/revistaici/article/view/24945/15542. Acesso em: 3 mar. 2018.

SHINTAKU, M. DUQUE, C. SUAIDEN, E. J. Análise da adesão às tendências da Ciência pelos repositórios institucionais brasileiros. InCID: Revista de Ciência da Informação e Documentação. Ribeirão Preto, v. 6, n. 2, p. 148-169, set. 2015/fev. 2016. Disponível em: https://www.revistas.usp.br/incid/article/view/89191/103994. Acesso em: 3 mar. 2018.

SILVA, S. D. LOUREIRO, J. M. M. Informação, memória e processos curatoriais: disrupções e diafanizações nos museus de história natural. Tendências da

Pesquisa Brasileira em Ciência da Informação, v.8, n.2, p. 280-300, jul./dez. 2015. Disponível em: http://inseer.ibict.br/ancib/index.php/tpbci/article/view/210/275. Acesso em: 6 mar. 2018.

VALERO, P. P. Curación de contenidos desde bibliotecas competencias, herramientas y aplicaciones. Ciência da Informação, Brasília, DF, v.45 n. 2, p.103117, maio/ago. 2016. Disponível em:

http://revista.ibict.br/ciinf/article/view/3805/3359. Acesso em: 3 mar. 2018.

ZANELLA, F. Documentar as Artes. Entre dois Pólos: um Arquivo de Objetos e Papeis e um Arquivo Nativo digital. InCID: Revista de Ciência da Informação e Documentação. Ribeirão Preto, v. 7, n. 2, p. 4-22, set. 2016/fev. 2017. Disponível 
em: https://www.revistas.usp.br/incid/article/view/121368/118568. Acesso em: 3 mar. 2018. 


\section{APÊNDICE B}

\section{Frequência de termos atribuídos aos artigos recuperados}

Curadoria Digital (17)

Curadoria (2)

Curadoria de Coleções (1)

Curadoria de Conteúdo (1)

Curadoria de Dados (3)

Preservação Digital (11)

Preservação da Informação Digital (1)

Preservação de Dados (1)

Arquivo

Arquivo Aberto

Arquivo de Arte Visual

Arquivo Digitais

Arquivo Permanentes

Arquivo de Páginas Web

Repositório de Dados

Repositório Digital de Dados de Pesquisa

Repositório Científico

Repositório Digital

Repositório Institucional

Competência Informacional (2)

Competência Profissional (3) 
Biblioteca (2)

Biblioteca Universitária

Biblioteca Digital

Dado de Pesquisa (5)

Ciência Aberta (4)

Dado Aberto (2)

Dado Científico (2)

Museu da Pessoa

Museu de Arte do Rio

Museu (2)

Museu de História Natural

Informação e Tecnologia (3)

Design da Informação (3)

E-Ciência (3)

Acesso Aberto

Acesso de Dados

Acesso Livre

Acervo Digital

Big Data (2) 
Gestão de Dados de Pesquisa (2)

Metadado (2)

Twitter (2)

Web Colaborativa (2)

\section{Lista de Termos Únicos}

Arquitetura da Informação

Arte Italiana

Arte Não-Realizada

Autoria

Autoridade

Bibliotecário Acadêmico

Caderno Eletrônico de Laboratório

Ciclo de Vida dos Dados

Ciência da Informação

Ciência de Dados

Cientista de Dados

Coleção Especial

Compartilhamento de Informação

Comunicação Científica

Critérios de Comparação

Crowdsourcing

Cultura

Curador de Conteúdos 
Dimensão Analíticas

Fonte de Informação

Formação Profissional

Gestão da Informação Digital

Gestão de Dados de Investigação

Governança

Informação Digital

Integração

Interoperabilidade

Livro de Artista

Memória na Internet

Mídia Social

Objeto Digital

Ontologia

Perfil de Aplicação

Plataforma Digital

Prática de Arte Contemporânea

Prática de Preservação Digital

Profissional Bibliotecário 